\title{
Debt Enforcement Around the World
}

\section{Citation}

Djankov, Simeon, Oliver Hart, Caralee McLiesh, and Andrei Shleifer. 2008. Debt enforcement around the world. Journal of Political Economy 116(6): 1105-1149.

\section{Published Version}

http://dx.doi.org/10.1086/595015

\section{Permanent link}

http://nrs.harvard.edu/urn-3:HUL.InstRepos:2961825

\section{Terms of Use}

This article was downloaded from Harvard University's DASH repository, and is made available under the terms and conditions applicable to Other Posted Material, as set forth at http:// nrs.harvard.edu/urn-3:HUL.InstRepos:dash.current.terms-of-use\#LAA

\section{Share Your Story}

The Harvard community has made this article openly available.

Please share how this access benefits you. Submit a story.

Accessibility 


\title{
Debt Enforcement around the World
}

\section{Simeon Djankov}

World Bank

Oliver Hart

Harvard University

Caralee McLiesh

World Bank

\section{Andrei Shleifer}

Harvard University

\begin{abstract}
Insolvency practitioners from 88 countries describe how debt enforcement will proceed against an identical hotel about to default on its debt. We use the data on time, cost, and the likely disposition of the assets (preservation as a going concern vs. piecemeal sale) to construct a measure of the efficiency of debt enforcement in each country. This measure is strongly correlated with per capita income and legal origin and predicts debt market development. Several characteristics of debt enforcement procedures, such as the structure of appeals and availability of floating charge finance, influence efficiency.
\end{abstract}

We thank Osborne Jackson, Julien Levis, Tatiana Nenova, and Justin Yap for assistance with this project; Douglas Baird, Julian Franks, Nicola Gennaioli, Rafael La Porta, Giacomo Ponzetto, Stefano Rossi, David Scharfstein, Ivo Welch, an editor, and two anonymous referees for helpful comments; and the World Bank, the Kauffman Foundation, and the National Science Foundation for financial support. We also thank the International Bar Association for substantial cooperation with this project. The data used in this paper can be downloaded from http://www.economics.harvard.edu/faculty/shleifer/files/Debt _enforcement_database_JPE.xls.

[Journal of Political Economy, 2008, vol. 116, no. 6]

(C) 2008 by The University of Chicago. All rights reserved. 0022-3808/2008/11606-0003 $\$ 10.00$ 


\section{Introduction}

Debt is one of the most useful contracts in every economy since it enables firms to finance investment and individuals to smooth consumption. But, like any other contract, debt needs to be enforced. To enforce debt contracts, societies create a variety of legal mechanisms or institutions that allow lenders to go after a defaulting borrower's income and assets without resorting to violence. Some of the debt enforcement institutions, such as some foreclosure proceedings, do not require courts. However, in the case of firms with multiple creditors, many societies rely on courts to enforce debt contracts, usually through bankruptcy or insolvency procedures.

Despite the importance of debt enforcement, insolvency institutions are generally perceived to perform poorly, even in advanced market economies but especially in developing countries. This raises several questions: How poorly do these institutions function? Why do they function poorly? Are there ways to improve them? Are these reform strategies consistent with the other institutions and capabilities of a country?

To address these questions, we study debt enforcement with respect to an insolvent firm in 88 countries. We present insolvency practitioners in each country with the same case study of an insolvent firm. The case was developed jointly with the Committee on Bankruptcy of the International Bar Association to be representative of insolvency of a midsize firm in many countries. The firm is a hotel with a given number of employees, capital and ownership structure, value as a going concern, and a lower value if sold piecemeal. ${ }^{1}$ The firm is otherwise identical across countries except that the economic values are all normalized by the country's per capita income.

We then ask each practitioner to describe in detail how debt enforcement for these case facts in his or her country will proceed, step by step. The detailed narratives provided and confirmed by the practitioners tell us which procedure is likely to be used in each country for debt enforcement (foreclosure, liquidation, or an attempt at reorganization) and allow us to compute the time and the cost of the chosen procedure, to learn whether the hotel will be kept together or sold piecemeal, and to use all these data to compute a measure of efficiency of the debt enforcement procedure for each country. We also collect detailed data on both legal and economic characteristics of the debt enforcement procedure for our case in each country. We can thus assess which institutional features are conducive to the economically efficient treatment of assets and overall efficiency—at least in our relatively simple case.

\footnotetext{
${ }^{1}$ We have also presented them with a case in which the value if sold piecemeal is higher, but that case had some problems and is not discussed in detail in this paper. For details, see Djankov et al. (2006).
} 
Comparing debt enforcement against essentially the same business in different countries has many advantages. First, it allows an analysis of the efficiency of these procedures, as well as of its determinants, with relatively less concern that we are comparing apples to oranges. Second, we provide quantitative measures of enforcement and so are less vulnerable to the critique, sometimes leveled against La Porta et al. (1997, 1998), that we are just looking at law on the books. Third, commonly defined measures of law enforcement across countries can be used in other comparative studies. Despite these advantages and despite the advice of insolvency experts in designing our case, the case study approach has several limitations, which we discuss later in the paper.

Our analysis is organized around the procedures that the respondents say are likely to be used in their countries to address the insolvency of the hotel. There are only three basic procedures used around the world: (1) foreclosure by the senior creditor, which may or may not involve a court; (2) liquidation; and (3) reorganization, which often leads to subsequent liquidation (we call this type of procedure "reorganization first"). ${ }^{2}$ Foreclosure serves as an important benchmark since, with only one senior creditor with socially correct incentives, it can at least conceptually achieve the efficient outcome. Because under our case facts foreclosure, which can be a contractual solution with no or minimal court involvement, can address insolvency without formal bankruptcy, the title of the paper is "debt enforcement" rather than bankruptcy or insolvency.

Our findings can be briefly summarized. Looking at worldwide averages, we find that all procedures are extremely time-consuming, costly, and inefficient. Only 36 percent of the countries achieve the efficient outcome of keeping the hotel as a going concern. Between the transaction costs of debt enforcement, the delay cost of the proceedings, and the loss from reaching the wrong outcome, a worldwide average of 48 percent of the hotel's value is lost in debt enforcement. We find that legal origins and per capita income are the most important cross-country determinants of efficiency. In addition, richer countries have a comparative advantage at more complex procedures (see also Djankov, Glaeser, et al. 2003; Franks and Lóránth 2005; Gennaioli and Rossi 2007; Ayotte and Yun 2009).

We also find that various specific economic and legal rules are associated with differences in efficiency of debt enforcement procedures across countries. Most important, many countries legally mandate deviations from absolute priority of the secured senior creditor. Such de-

\footnotetext{
${ }^{2}$ Baird (1986), White (1989), Baird and Rasmussen (2002), and LoPucki (2003) discuss the procedures used in the United States. Thorburn (2000) presents evidence in support of liquidation in Sweden. Bris, Welch, and Zhu (2006) present evidence that reorganization generates greater asset values than liquidation in the United States.
} 
viations are more pronounced in the poorer and the French legal origin countries. Looking at debt recovery by the senior creditor (a measure of ex ante efficiency) as opposed to ex post efficiency as the indicator of debt enforcement renders our findings on per capita income and legal origin even stronger.

We find that foreclosure works extremely well with "floating charge" debt securities, when the whole business is pledged as collateral, but poorly when only specific assets can be pledged. This result is consistent with the observation that, under our case facts, the senior creditor has the socially optimal incentives to dispose of the business as long as he can gain control of it in default. We also find, in the same spirit, that the efficiency of foreclosure rises when the senior creditor is allowed to take collateral in an out-of-court procedure. ${ }^{3}$ Turning to insolvency proceedings, we find that legal rules that require the company to suspend operations, or that allow suppliers and customers to rescind contracts while the company is in bankruptcy, reduce efficiency. Moreover, extensive appeal of judicial decisions during insolvency proceedings and the failure to continue the proceedings during appeal are both detrimental to efficiency. Finally, our measures of the efficiency of debt enforcement are economically and statistically significant predictors of the development of debt markets across countries.

Section II presents our case and the data collection procedure. Section III describes how we go from the information collected from insolvency practitioners to data. Section IV presents the basic results on the time, cost, resolution, and efficiency of the procedures and their determinants in 88 countries. Section $\mathrm{V}$ focuses on legal violations of absolute priority. Section VI looks at the specific structural features of the debt enforcement procedures. Section VII analyzes cross-country determinants of private debt market development. Section VIII presents conclusions.

\section{The Case Study}

Our data are based on answers to a questionnaire completed by attorneys and judges who are members of Section $\mathrm{J}$ of the International Bar Association (IBA). Section J's members are practitioners in the areas of insolvency, restructuring, and creditors' rights. In 2002, we approached the section's chair with a request to develop a research survey that compares bankruptcy systems around the world. We asked for pro bono cooperation in developing the questionnaire, piloting it, and administering it worldwide using Section J members as respondents. The IBA

\footnotetext{
${ }^{3}$ Franks and Sussman (2005) provide compelling evidence that floating charge debt works extremely well as the basis of foreclosure of small and medium-size U.K. companies.
} 
approved the proposal and assigned attorneys from the United Kingdom, Germany, and Spain, as well as bankruptcy judges from Japan and the United States, to cooperate with us on the initial case study and questionnaire. The initial case and the questionnaire were then piloted in Argentina, Brazil, the Czech Republic, France, Germany, Greece, Italy, Japan, South Africa, Spain, the United Kingdom, and the United States. Following these pilots, several modifications were made to ensure compatibility of the case facts with different legal systems.

We then asked six bankruptcy attorneys from developing countries (Botswana, Egypt, Ghana, Guatemala, India, and Kazakhstan) to complete the revised survey, to comment on its relevance to their countries, and to suggest changes. This second pilot yielded several modifications, including most importantly the suggestion to simplify the case to a single bank creditor, since it was unusual in the experience of these attorneys for a hotel to deal with multiple banks. The attorneys also recommended the inclusion of multiple suppliers as nonfinancial creditors, since this was a common feature in bankruptcy cases. We were also asked to add questions on the relationship between out-of-court foreclosure and reorganization procedures. Finally, the attorneys insisted that we give more prominence to the tax administration, which in several of these countries is the likely party to initiate bankruptcy proceedings. The case was then adjusted to incorporate these recommendations.

The newly revised survey was sent to members of Section $\mathrm{J}$ in each country by the chair. Once the completed surveys were returned, the research team conducted several calls with each respondent to clarify their answers and then conference calls with all respondents from a given country to achieve a consensus answer (most disagreements arose from misunderstandings of case facts). In total, 344 attorneys and 34 judges from 88 countries participated in the survey, but our methodology uses one consensus answer per country. Four rounds of the survey were conducted, including January 2003 (pilot survey), 2004, 2005, and 2006. The paper uses the data benchmarked to January 2006.

The sample covers all countries with income per capita greater than US $\$ 1,000$ and population more than 1.5 million in $2005 .{ }^{4}$ It includes 30 high-income, 20 upper-middle-income, and 38 lower-middle-income countries. Eight countries are in the East Asia region, 22 in Eastern Europe, 18 in Latin America, 13 in the Middle East, four in Africa, and one in South Asia; 22 are OECD countries.

The respondents are presented with a standardized case study of an insolvent firm called Mirage. Mirage is a limited liability, domestically owned hotel business located in the most populous city. Mirage has 201

\footnotetext{
${ }^{4}$ The World Bank defines a small state to be one with a population of less than 1.5 million.
} 
employees and 50 suppliers, each of which is owed money for its last delivery. Five years ago, Mirage borrowed from Bizbank, a domestic bank, and bought real estate (the hotel building), using it as security for the Bizbank loan. The loan has a 10-year term. Mirage has observed the payment schedule and all other conditions of the loan up to now.

Mirage is owned 51 percent by Mr. Douglas, its founder, who is also the chairman of the supervisory board. No other shareholder has above 5 percent of the voting power. There is a professional general manager, with no idiosyncratic human capital. The total amount of debt outstanding is set at 136 units. Unsecured creditors (including suppliers, the tax authority, and the employees) hold 36 units (26 percent) as a whole, or 12 units for each group. The balance of total debt is held by Bizbank (74 percent)—equivalent to 100 units. With only one large secured creditor, Mirage's bankruptcy presents a relatively simple case (although in some countries, this creditor does not have absolute priority).

In the past, Mirage has always turned a profit, covering all costs and regularly paying the loan from Bizbank. The company had projected to continue this performance into the future. However, recently Mirage experienced an unexpected operating loss due to worsened industry conditions. The management expects that, in the next 2 years, Mirage can cover its operating expenses from projected revenues (and so does not need additional cash to operate) but will not make enough money to pay back Bizbank. As a consequence, Mirage is about to default. Bizbank has not seen the new projections yet.

We stipulate that the value of Mirage is higher as a going concern than if sold piecemeal. Specifically, Mirage is worth 100 units as a going concern (equal to the value owed to Bizbank) and 70 units if sold piecemeal (buildings, furniture, etc.). Since Mirage is experiencing a temporary downturn, the economically efficient outcome is to keep it a going concern. Under these assumptions, Bizbank has socially correct incentives if it gains control of Mirage because it is owed the maximum potential value of the company. The efficient strategy for our case facts is clear: to turn Mirage over to Bizbank and to let Bizbank run it or sell it as a going concern.

Like Bizbank, other parties prefer to keep Mirage operating as a going concern and avoid piecemeal sale (although they would like a part of the proceeds). Mr. Douglas wants to keep the firm in operation under his control but does not care whether current management stays. Minority shareholders want to do likewise because with a piecemeal sale they get nothing. The management of Mirage wants to keep the firm in operation and keep their jobs. The suppliers prefer Mirage to continue operations, since this may make it more likely that they recover the trade credit due, and they want to continue doing business with Mirage. In countries in which wages do not have priority over secured 
creditors, workers want Mirage to continue in business since they may not get paid in full if it is sold piecemeal. Even where wages have priority, workers still prefer Mirage to continue operating, as long as they value their jobs. The tax administration will follow the procedure that maximizes its expected recovery rate. Other things equal, the tax administration wants Mirage to continue in business since future tax revenues are lost in a piecemeal sale.

The management of Mirage has full knowledge of the case facts presented above and therefore has a first-mover advantage. Bizbank will observe the payment default by Mirage tomorrow. However, the bank does not know whether Mirage's bad luck is likely to be prolonged. That information will be available only in the annual report published in 3 months' time. Shareholders, suppliers, the tax administration, and employees will become aware of the situation when they have access to the annual report.

As this description illustrates, our case is relatively simple and abstracts from a number of issues that have been the focus of bankruptcy scholarship in recent years. First, we focus on formal insolvency proceedings and ignore informal workouts (Gilson, John, and Lang 1990; Asquith, Gertner, and Scharfstein 1994). Claessens and Klapper (2005) find that workouts are common in countries with concentrated banking relationships; Franks and Lóránth (2005) have a similar finding for Hungary, where bankruptcy is highly inefficient. However, workouts often fail and are more likely to fail when, as with Bizbank, there are multiple unsecured creditors.

Second, the security on which Mirage defaults is straight debt; by assumption we do not allow complex financial structures that can permit Mirage to circumvent formal bankruptcy. Some of the problems we discuss can be avoided with convertible debt, for example, although such debt does not deal with the difficulties posed by unsecured creditors and hence does not take care of central issues of our case. Recent research shows that financial contracts indeed adjust to the legal environment but also that judges in poor countries often fail to enforce them (Lerner and Schoar 2005; Gennaioli and Rossi 2007; Qian and Strahan 2007).

Third, as advised by bankruptcy specialists from developing countries, we have only one senior secured creditor (along with employees, suppliers, and the government, which are unsecured). More complex capital structures, which we are advised are uncommon for midsize firms, would create further complications (Bebchuk 1988; Gertner and Scharfstein 1991; Aghion, Hart, and Moore 1992; Bolton and Scharfstein 1996; Stromberg 2000; Berglof, Roland, and von Thadden 2007).

Fourth, we assume that the creditor knows from the start that preservation as a going concern is efficient for Mirage. One argument for 
court-supervised bankruptcy is that such knowledge is unavailable, and bankruptcy facilitates the discovery of the efficient disposition.

Fifth, the hotel does not require any additional financing to continue operations; its problem is the inability to pay the outstanding debt. This assumption may bias the results in favor of foreclosure since one reason for bankruptcy protection is to allow the firm to raise additional finance, something it does not need to do in our case.

Sixth, the hotel is small and not important enough for politicians or judges to try to keep it going "in the public interest." Politicization of bankruptcy is also an important concern (Weiss and Wruck 1998; Chang and Schoar 2007; Lambert-Moglianski, Sonin, and Zhuravskaya 2007).

Seventh, our case facts explicitly rule out tunneling of the hotel's assets during debt enforcement. In the developing countries in particular, tunneling of the firm by the controlling shareholder may present a major problem for creditors, creating pressure for a quick piecemeal sale (Johnson et al. 2000; La Porta, Lopez-de-Silanes, and Zamarripa 2003; Gennaioli and Rossi 2007). This means that some institutional arrangements, such as automatically shutting down a firm during insolvency proceedings, will perform extremely badly under our no tunneling assumption but make sense if keeping the firm alive encourages the diversion of assets. On the other hand, complex bankruptcy procedures might work even worse with tunneling than without.

\section{Data}

\section{A. Procedures}

The legal procedures that respondents choose as the most likely option for resolving Mirage's insolvency include foreclosure, liquidation, and reorganization. Each procedure can lead either to Mirage continuing operation as a going concern or to its piecemeal sale (fig. 1).

Foreclosure is a debt enforcement procedure aimed at recovering money owed to secured creditors. Foreclosure does not protect unsecured creditors, who must rely on separate insolvency proceedings to recover the amounts owed them. In some countries, an insolvent company (or unsecured creditors) can cause a stay of foreclosure proceedings by initiating a reorganization or liquidation procedure, whereas in other countries, a reorganization or liquidation filing does not stop foreclosure. In the latter case, liquidation procedures may take place in tandem with or after foreclosure.

Foreclosure can be an entirely out-of-court procedure, in which a receiver steers the company to a sale of assets (either piecemeal or as a going concern). Indeed, the appointment of such a receiver can be part of the debt contract. In other countries, a court oversees foreclo- 


\section{Procedures}

\section{Outcomes}

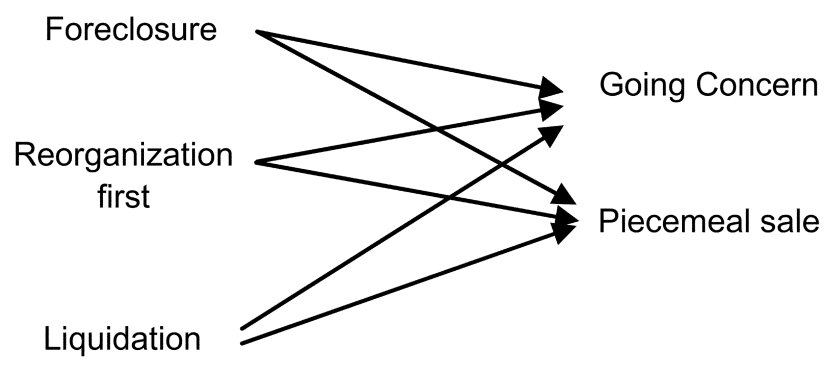

Fig. 1.-Procedures and outcomes

sure, although it is typically less involved than in bankruptcy. Some countries allow a creditor to take security over an entire business-often known as a "floating charge." Under our case facts, foreclosure under a floating charge gives Bizbank socially optimal incentives to dispose of Mirage. In other countries, Mirage as a business is not legally valid collateral, which obviously distorts Bizbank's incentives.

Liquidation is the procedure of winding up a company under court supervision. ${ }^{6}$ In principle, it may lead to a sale of Mirage as a going concern and does not necessarily result in the piecemeal sale of its assets.

Reorganization is a court-supervised procedure aimed at rehabilitating companies in financial distress. It is not available in all countries. Reorganization protects the company while it attempts to rehabilitate itself; once reorganization begins, creditors generally may not enforce their claims against the company. The current management of Mirage may or may not retain control of the company during reorganization.

In some instances, as is the case with Chapter 7 and 11 proceedings in the United States, liquidation and reorganization are separate procedures. A petitioner must choose between the two. In other countries, there exists a single insolvency procedure, and the company may be directed either to the liquidation or to the reorganization "track."

Regardless of the nature of the reorganization procedure, in many

\footnotetext{
${ }^{5}$ We use the term "floating charge" when the assets of the entire business can be pledged as collateral. Countries use different terms for this concept, including "enterprise mortgage," "enterprise charge," or "pledge of business." In the United Kingdom, "floating charge" can be used more narrowly, for instance, by excluding inventory from the pool of pledged assets, but it is still possible to pledge the assets of an entire business.

${ }^{6}$ We consider here compulsory liquidation, where either a creditor files a liquidation petition or the law requires that an insolvent debtor file the same petition under certain circumstances. Another process, voluntary liquidation not required by law, is outside the scope of our study.
} 
countries Mirage may still end up in liquidation after an initial attempt at reorganization.

\section{B. Responses}

We present the case to respondents and first ask them to outline the procedures available by law in the case of Mirage. They then indicate which legal procedure is most likely to be followed in the case of Mirage-given their experience, their country's laws, and the assumptions of the case study. Respondents explain which procedure is chosen and which party—Bizbank, Mirage, or another—selects it. Mirage has a firstmover advantage since its management knows it will default. In countries in which a debtor can seek relief from enforcement by unilaterally applying for reorganization, Mirage is likely to initiate a reorganization proceeding since management wishes it to continue as a going concern. In countries in which liquidation and reorganization do not automatically stay foreclosure proceedings and foreclosure is faster and cheaper than other procedures, Bizbank will initiate foreclosure. In countries in which Mirage's financial position (it has negative net worth and is in default) automatically triggers liquidation, liquidation is the most likely procedure.

In the United States, for example, Mirage will successfully apply for Chapter 11 reorganization. Reorganization imposes an automatic stay on enforcement and offers the best chance of keeping the firm in operation and current management in control. Mirage's first-mover advantage allows it to take this course of action. In the United Kingdom, our respondent reported that Bizbank retains the right to appoint an administrative receiver under a foreclosure measure because its security was granted before the effective date of the Enterprise Act, 2002. Administrative receivership mainly benefits the secured creditor; if the security had taken effect after the effective date of the Enterprise Act, Bizbank would not have been able to appoint an administrative receiver and Mirage would have appointed an administrator, with the goal of preserving it as a going concern. In Greece, commencement of reorganization requires the consent of 60 percent of all creditors, including at least 40 percent of secured creditors, so reorganization is possible only with Bizbank's consent. Bizbank is unlikely to offer such consent because suppliers to Mirage in reorganization will become senior to Bizbank. Enforcement of the security right by Bizbank is also possible in Greece but expensive. Our survey shows that liquidation is the most likely choice and that Mirage is likely to be sold piecemeal.

We also ask respondents to describe how the insolvency process evolves in the most likely scenario under the assumptions of the case. They describe the main sequence of steps and associated time from the 
moment of filing until the payment of all parties, including the main points of delay such as appeals. In Singapore, for example, there are eight main steps to the insolvency case. First, Bizbank would issue a formal demand for the monies due under the security, normally within 14 days. Since Mirage is unable to pay, Bizbank would then appoint a receiver to manage Mirage, who would assume control of the business with an objective to sell it as a going concern and recover the debt owed to Bizbank. This step typically takes 4 weeks. Marketing submissions are received and analyzed (requiring 2 weeks), and a marketing program agreed and implemented ( 5 weeks). Negotiations with interested parties and execution of the contract of sale for Mirage take place (4 weeks), followed by completion of the contract of sale (12 weeks). Unsecured creditors are likely to appeal the matter on the grounds that the sale price is not reasonable, delaying the proceedings by 2 months assuming that there is no real evidence to support their challenge (as under the facts of the case). Funds are disbursed and final reports are prepared (3 weeks).

Respondents predict whether Mirage continues operating as a going concern after the resolution of the case and justify their choice with written arguments. In Italy, for example, reorganization plans may be approved by the court only if 40 percent of unsecured creditor debt is satisfied in the plan and 100 percent of secured creditor debt is satisfied in the plan. Since the value of Mirage is exactly equal to the amount owed Bizbank but is not enough to satisfy unsecured creditors, the reorganization plan is not accepted and the firm is automatically sold piecemeal. In the Czech Republic, the administrator is paid more for each sale that is conducted, thus increasing the incentive for a piecemeal sale.

Finally, respondents estimate the cost of the proceeding borne by all parties. These costs include court fees, attorney fees, notification fees, publication fees, administrator fees, assessor and inspector fees, asset storage and preservation costs, liquidation/auctioneer fees, government fees/levies, and other fees respondents are asked to describe. In most countries, the largest component of costs is attorney fees.

\section{Main Variables}

Table 1 defines the variables used in the analysis. Four main variables are recorded from survey responses. First, we document the time to resolve the insolvency process. Time covers the period from the moment that Mirage defaults until its fate is realized: it is kept as a going concern or sold piecemeal. Time includes all delays from disputed claims and appeals that are likely given the assumptions of the case study. In some countries, Bizbank is not paid immediately when the insolvency process 
TABLE 1

DESCRIPTION OF THE VARIABLES

\begin{tabular}{|c|c|}
\hline Variable & Description \\
\hline \multicolumn{2}{|l|}{ A. Main variables: } \\
\hline Foreclosure & $\begin{array}{l}=1 \text { if Mirage is most likely to undergo a foreclosure } \\
\text { or similar debt enforcement proceeding, } 0 \\
\text { otherwise }\end{array}$ \\
\hline Liquidation & $\begin{array}{l}=1 \text { if Mirage is most likely to undergo a liquidation } \\
\text { proceeding, } 0 \text { otherwise }\end{array}$ \\
\hline Reorganization & $\begin{array}{l}=1 \text { if Mirage is most likely to undergo a reorganiza- } \\
\text { tion proceeding, } 0 \text { otherwise }\end{array}$ \\
\hline Time & $\begin{array}{l}\text { Estimated duration, in years, of the time to resolve } \\
\text { the insolvency case of Mirage; measures the dura- } \\
\text { tion from the moment of Mirage's default to the } \\
\text { point at which the fate of Mirage is determined, } \\
\text { i.e., when Mirage is either sold as a going concern, } \\
\text { sold piecemeal, or successfully reorganized }\end{array}$ \\
\hline Time to payment & $\begin{array}{l}\text { Estimated duration, in years, of the time from the } \\
\text { moment of Mirage's default to the point at which } \\
\text { the secured creditor receives payment }\end{array}$ \\
\hline Cost & $\begin{array}{l}\text { Estimated cost of the debt enforcement proceeding } \\
\text { for Mirage, reported as a percentage of the value } \\
\text { of the estate, borne by all parties; costs include } \\
\text { court/bankruptcy authority costs, attorney fees, } \\
\text { bankruptcy administrator fees, accountant fees, no- } \\
\text { tification and publication fees, assessor or inspector } \\
\text { fees, asset storage and preservation costs, auction- } \\
\text { eer fees, government levies, and other associated } \\
\text { insolvency costs }\end{array}$ \\
\hline Going concern & $\begin{array}{l}=1 \text { if Mirage continues operating as a going con- } \\
\text { cern both throughout and upon completion of the } \\
\text { insolvency process, } 0 \text { otherwise }\end{array}$ \\
\hline Lending rates & $\begin{array}{l}\text { The bank lending rate to the private sector (source: } \\
\text { International Monetary Fund's International Finan- } \\
\text { cial Statistics [IFS] online database, line } 60 \text { P.ZF): } \\
\text { line } 60 \mathrm{P} . \mathrm{ZF} \text { is defined as the "bank rate that usually } \\
\text { meets the short and medium term financing needs } \\
\text { of the private sector" (in cases in which lending } \\
\text { rates are not reported in the IFS, we obtain data } \\
\text { directly from central banks) }\end{array}$ \\
\hline Legal origin & $\begin{array}{l}\text { A dummy variable that identifies the legal origin of } \\
\text { the bankruptcy law of each country (the four ori- } \\
\text { gins are English, French, German and Nordic) }\end{array}$ \\
\hline GDP per capita & $\begin{array}{l}\text { Logarithm of gross national income per capita (Atlas } \\
\text { method), } 2004 \text { (source: World Development Indica- } \\
\text { tors 2005) }\end{array}$ \\
\hline \multicolumn{2}{|l|}{$\begin{array}{l}\text { B. Characteristics of the } \\
\text { insolvency system: }\end{array}$} \\
\hline $\begin{array}{l}\text { Statutory time limits on } \\
\text { appeals }\end{array}$ & $\begin{array}{l}=1 \text { if there are time limits that restrict the duration } \\
\text { of any appeal of the judgment by any party, } 0 \\
\text { otherwise }\end{array}$ \\
\hline $\begin{array}{l}\text { Out-of-court seizure and } \\
\text { sale }\end{array}$ & $\begin{array}{l}=1 \text { if the secured creditor may seize and sell its col- } \\
\text { lateral without court approval, judgment, or en- } \\
\text { forcement; }=0 \text { if court approval, judgment, or en- } \\
\text { forcement is required to enforce security }\end{array}$ \\
\hline
\end{tabular}


TABLE 1

(Continued)

\begin{tabular}{|c|c|}
\hline Variable & Description \\
\hline $\begin{array}{l}\text { No judgment for } \\
\text { enforcement }\end{array}$ & $\begin{array}{l}=1 \text { if the secured creditor may enforce its security } \\
\text { in either an enforcement court or an out-of-court } \\
\text { procedure, without first obtaining a judgment au- } \\
\text { thorizing it to do so; }=0 \text { if a court judgment is re- } \\
\text { quired before proceeding to enforcement }\end{array}$ \\
\hline Floating charge & $\begin{array}{l}=1 \text { if the assets of the entire business can be } \\
\text { pledged as collateral, } 0 \text { otherwise }\end{array}$ \\
\hline Specialized court & $\begin{array}{l}=1 \text { where the authority with jurisidiction in the case } \\
\text { of Mirage is either a specialized bankruptcy court } \\
\text { or a specialized bankruptcy administrative authority, } \\
0 \text { otherwise; a specialized bankruptcy court would } \\
\text { generally have jurisdiction over liquidation and re- } \\
\text { organization, but not foreclosure/debt enforce- } \\
\text { ment proceedings }\end{array}$ \\
\hline $\begin{array}{l}\text { Case proceeds on } \\
\text { appeal of insolvency }\end{array}$ & $\begin{array}{l}=1 \text { if the insolvency case is not automatically sus- } \\
\text { pended upon appeal of the order initiating the in- } \\
\text { solvency process or if the insolvency order cannot } \\
\text { be appealed at all; }=0 \text { if the case is suspended un- } \\
\text { til resolution of the appeal }\end{array}$ \\
\hline $\begin{array}{l}\text { Same judge for appeal } \\
\text { of insolvency }\end{array}$ & $\begin{array}{l}=1 \text { if an appeal of the initiation of the insolvency } \\
\text { case is handled by the same judge supervising the } \\
\text { insolvency case; }=0 \text { if the appeal is heard by a dif- } \\
\text { ferent judge in an appeals court }\end{array}$ \\
\hline $\begin{array}{l}\text { Case proceeds on } \\
\text { appeal of liquidation }\end{array}$ & $\begin{array}{l}=1 \text { if a sale in liquidation is executed even on ap- } \\
\text { peal of the liquidation order or if the liquidation } \\
\text { order cannot be appealed at all; }=0 \text { if the case is } \\
\text { suspended until resolution of the appeal }\end{array}$ \\
\hline $\begin{array}{l}\text { Same judge for appeal } \\
\text { of liquidation }\end{array}$ & $\begin{array}{l}=1 \text { if an appeal of the order to liquidate Mirage is } \\
\text { handled by the same judge supervising the insol- } \\
\text { vency case; }=0 \text { if the appeal is heard by a differ- } \\
\text { ent judge in an appeals court }\end{array}$ \\
\hline $\begin{array}{l}\text { Case proceeds on claim } \\
\text { amount dispute }\end{array}$ & $\begin{array}{l}=1 \text { if the insolvency case is not automatically sus- } \\
\text { pended when a creditor disputes a claim amount } \\
\text { or if the claim amount cannot be appealed at all; }= \\
0 \text { if the case is suspended until resolution of the } \\
\text { appeal }\end{array}$ \\
\hline $\begin{array}{l}\text { Same judge for claim } \\
\text { amount dispute }\end{array}$ & $\begin{array}{l}=1 \text { if an appeal of the amount of the claim is han- } \\
\text { dled by the same judge supervising the insolvency } \\
\text { case; }=0 \text { if the appeal is heard by a different } \\
\text { judge in an appeals court }\end{array}$ \\
\hline $\begin{array}{l}\text { Reorganization attempt } \\
\text { required }\end{array}$ & $\begin{array}{l}=1 \text { if by law Mirage must first attempt reorganiza- } \\
\text { tion before proceeding to liquidation; }=0 \text { if it is } \\
\text { possible for Mirage to enter liquidation first }\end{array}$ \\
\hline $\begin{array}{l}\text { Automatic stay on } \\
\text { enforcement }\end{array}$ & $\begin{array}{l}=1 \text { if the secured creditor may not enforce its secu- } \\
\text { rity against Mirage upon commencement of the in- } \\
\text { solvency proceedings, } 0 \text { otherwise }\end{array}$ \\
\hline $\begin{array}{l}\text { Automatic stay on } \\
\text { lawsuits }\end{array}$ & $\begin{array}{l}=1 \text { if lawsuits against Mirage are automatically } \\
\text { stayed upon commencement of insolvency proceed- } \\
\text { ings, } 0 \text { otherwise }\end{array}$ \\
\hline $\begin{array}{l}\text { Firm must cease } \\
\text { operating }\end{array}$ & $\begin{array}{l}=1 \text { if Mirage must cease operations upon com- } \\
\text { mencement or during the insolvency proceedings, } \\
0 \text { otherwise }\end{array}$ \\
\hline $\begin{array}{l}\text { Contracts may be } \\
\text { rescinded }\end{array}$ & $\begin{array}{l}=1 \text { if suppliers and customers may rescind contracts } \\
\text { with Mirage without penalty upon the initiation of } \\
\text { insolvency proceedings, } 0 \text { otherwise }\end{array}$ \\
\hline
\end{tabular}

1117 
TABLE 1

(Continued)

\begin{tabular}{|c|c|}
\hline Variable & Description \\
\hline $\begin{array}{l}\text { Restrictions on } \\
\text { dismissals }\end{array}$ & $\begin{array}{l}=1 \text { if Mirage is restricted from dismissing employees } \\
\text { upon the initiation of insolvency proceedings, } 0 \\
\text { otherwise }\end{array}$ \\
\hline Management remains & $\begin{array}{l}=1 \text { if management remains in control of decisions } \\
\text { in the ordinary course of business during the reso- } \\
\text { lution of the insolvency proceeding; = } 0 \text { if man- } \\
\text { agement is automatically dismissed or must be su- } \\
\text { pervised or seek approval from the insolvency } \\
\text { administrator or court for decisions in the ordinary } \\
\text { course of business }\end{array}$ \\
\hline $\begin{array}{l}\text { Creditor approves } \\
\text { administrator }\end{array}$ & $\begin{array}{l}=1 \text { if the secured creditor has the right to approve } \\
\text { the appointment of the insolvency administrator; }= \\
0 \text { if only the court, the debtor, and/or other partic- } \\
\text { ipants appoint the administrator }\end{array}$ \\
\hline $\begin{array}{l}\text { Creditor dismisses } \\
\text { administrator }\end{array}$ & $\begin{array}{l}=1 \text { if the secured creditor may dismiss or must ap- } \\
\text { prove the dismissal of the insolvency administrator; } \\
=0 \text { if only the court, the debtor, and/or other } \\
\text { participants dismiss the administrator }\end{array}$ \\
\hline $\begin{array}{l}\text { Administrator paid on } \\
\text { market value }\end{array}$ & $\begin{array}{l}=1 \text { if the insolvency administrator is remunerated } \\
\text { on the basis of the market value of the insolvency } \\
\text { estate; }=0 \text { if the insolvency administrator is remu- } \\
\text { nerated on the basis of the book value of assets or } \\
\text { on a daily rate }\end{array}$ \\
\hline $\begin{array}{l}\text { Automatic trigger for } \\
\text { liquidation }\end{array}$ & $\begin{array}{l}=1 \text { if an "automatic trigger" mechanism can initiate } \\
\text { insolvency; an automatic trigger is defined as a set } \\
\text { of circumstances—-such as on the period of default } \\
\text { or ratio of assets to liabilities-under which Mirage } \\
\text { must by law apply for insolvency proceedings }\end{array}$ \\
\hline $\begin{array}{l}\text { Proof of reorganization } \\
\text { prospects }\end{array}$ & $\begin{array}{l}=1 \text { if Mirage must submit proof of reorganization } \\
\text { prospects before reorganization proceedings may } \\
\text { commence }=0 \text { if Mirage may commence reorgan- } \\
\text { ization proceedings without evidence that the pro- } \\
\text { cedure may be successful }\end{array}$ \\
\hline Creditors vote directly & $\begin{array}{l}=1 \text { if secured creditors vote directly on the reorgan- } \\
\text { ization plan; }=0 \text { if secured creditors vote in com- } \\
\text { mittee or not at all }\end{array}$ \\
\hline \multicolumn{2}{|l|}{ C. Other variables: } \\
\hline Creditor rights & $\begin{array}{l}\text { Index aggregating creditor rights, following La Porta } \\
\text { et al. (1998); the index ranges from } 0 \text { to } 4 \text { (source: } \\
\text { Djankov et al. 2007) }\end{array}$ \\
\hline Information sharing & $\begin{array}{l}=1 \text { if either a public credit registry or a private } \\
\text { credit bureau operates in the country, } 0 \text { otherwise } \\
\text { (source: Djankov et al. 2007) }\end{array}$ \\
\hline Private credit/GDP & $\begin{array}{l}\text { Ratio of credit from deposit-taking financial institu- } \\
\text { tions to the private sector (IFS lines } 22 \mathrm{~d} \text { and } 42 \mathrm{~d} \text { ) } \\
\text { to GDP (IFS line 99b; source: IMF IFS database) }\end{array}$ \\
\hline GDP & $\begin{array}{l}\text { Logarithm of gross national product (current U.S. } \\
\text { dollars), average 2002-4 (source: World Develop- } \\
\text { ment Indicators 2005) }\end{array}$ \\
\hline GDP per capita growth & $\begin{array}{l}\text { Average annual growth in gross domestic product per } \\
\text { capita from } 1980 \text { to } 2004 \text { (source: World Develop- } \\
\text { ment Indicators 2005) }\end{array}$ \\
\hline
\end{tabular}


TABLE 1

(Continued)

\begin{tabular}{|c|c|}
\hline Variable & Description \\
\hline $\begin{array}{l}\text { Contract enforcement } \\
\text { days }\end{array}$ & $\begin{array}{l}\text { Number of days to resolve a payment dispute through } \\
\text { courts; data are based on the methodology in Djan- } \\
\text { kov, LaPorta, et al. (2003) but describe the number } \\
\text { of calendar days to enforce a contract of unpaid } \\
\text { debt worth } 50 \% \text { of the country's GDP per capita; } \\
\text { the variable is constructed as at January } 2003 \text {. } \\
\text { (source: Djankov, La Porta, et al. 2003). }\end{array}$ \\
\hline
\end{tabular}

is resolved. Accordingly, we also define time to payment as the time from default until Bizbank is paid. Of course, time is relevant for computing the efficiency of debt enforcement, whereas time to payment is relevant for computing Bizbank's recovery rate (Davydenko and Franks 2008). Time and time to payment are reported in years.

Next, we record the cost to complete the insolvency proceeding, expressed as a percentage of the bankruptcy estate at the time of entry into bankruptcy. The bankruptcy estate is the greater of the going concern and piecemeal sale values, which is 100 .

Third, we create a dummy variable, $G C$, equal to one if Mirage continues operating as a going concern (the efficient outcome here), upon completion of the insolvency process, and to zero if Mirage is sold piecemeal.

To assess the efficiency of each procedure, we need to make two additional assumptions that are not covered in the responses we have received. First, we need to make an assumption as to whether the cost of debt enforcement is incurred at the beginning or at the end. We assume that it is incurred at the end, which gives an advantage to relatively poor countries with high interest rates and costs. Second, we need to make an assumption as to the value Mirage generates while in debt enforcement proceedings. We assume that Mirage just covers its variable costs and generates no value during the insolvency process. This assumption holds regardless of whether Mirage operates as a going concern during the insolvency process or is closed down. This assumption obviously makes bankruptcy costlier for the poorer countries, with longer durations of proceedings and higher interest rates. In Section IV, we examine the robustness of our results with respect to changing each of these two assumptions.

Under these assumptions, we calculate a measure of efficiency, defined as the present value of the terminal value of the firm after bankruptcy costs, or

$$
E=\frac{100 \times G C+70 \times(1-G C)-100 \times c}{(1+r)^{t}} .
$$


Here $G C$ equals one if Mirage continues as a going concern and zero otherwise, $c$ is the cost, $t$ is the time to resolve insolvency, and $r$ is the nominal lending rate. Throughout, we examine the robustness of the results to assuming the same 8 percent rate for all countries.

We organize the data by income levels and the legal origin of a country's bankruptcy laws. Legal origin is obtained from a study of the origin of bankruptcy laws. There are four main insolvency legal origins: English, French, German, and Nordic. The coding is similar to the general commercial legal origin reported in La Porta et al. (1997, 1998), with some exceptions. For example, the commercial and company laws in Iran, Saudi Arabia, and the United Arab Emirates are based on English laws, but their bankruptcy laws are of French tradition-via France, Egypt, and Kuwait, respectively. Although Japan and Korea are of German commercial legal origin, their bankruptcy codes are based on English law. Switzerland, Russia, and Bulgaria base their bankruptcy laws on the French tradition; their commercial laws are of German origin.

In addition, we surveyed respondents on priority rules in bankruptcy (Sec. V) and on a range of structural features of the bankruptcy system (Sec. VI). The former come from responses to questions on the type of courts with jurisdiction over bankruptcy cases, rules on appeals in bankruptcy, restrictions on available bankruptcy procedures, rules to keep the business operating as a going concern, and information on which participants control the bankruptcy process. Twenty-four of these questions for which we have adequate answers (and which are relevant for our case) were coded for the analysis. These variables were verified from the available laws and public information.

\section{Basic Results}

We begin by noting the most basic features of the data. On average, the insolvency of Mirage takes 2.64 years to resolve, costs 14 percent of the estate, and preserves Mirage as a going concern in only 36 percent of the cases. The worldwide average efficiency measure is 51.97 percent, which means that almost half of Mirage's value is lost in debt enforcement. The fact that in our simple case-with one senior creditor, known going concern and piecemeal sale values, and no tunneling-half the value is lost in enforcement reinforces the common concern about the efficiency of bankruptcy.

There is tremendous variation among countries in time, cost, and efficiency. In 14 countries (all of them rich), insolvency takes less than a year to resolve, but in nine (mostly poor), it takes more than 5 years. The costs are not enormous on average, but in seven countries, typically those with very long proceedings, they consume over 30 percent of the estate, with the dominant cost being attorney fees. In Singapore, Neth- 
erlands, and Japan, our respondents indicate that only about 5 percent of the estate is wasted in debt enforcement. In Turkey and Angola, less than 7 percent of the estate is left, in present value terms, by the end of debt enforcement.

Given the large number of assumptions we made to arrive at these estimates of duration, cost, and efficiency, can we argue that they are plausible? We have pointed out already that the key case facts were developed jointly with bankruptcy practitioners in both rich and developing countries to make the case representative. An alternative way to consider plausibility is to correlate our estimates with other measures of efficiency of debt enforcement. Djankov, LaPorta, et al. (2003), using a very different methodology, propose a measure of formalism of judicial procedure, which is a measure of the regulation of legal proceedings for the collection of a bounced check. The authors show that formalism is a strong predictor of the inefficiency of the legal process. The correlation between the formalism measure and this paper's measure of efficiency of debt enforcement is -.522 , with a $p$-value of .000 . The fact that the two measures of efficiency of debt collection are so highly correlated despite being collected so differently is some indication of validity. In Section VII, we show that our measure of efficiency predicts debt market development, a further bit of evidence that our measure is plausible.

As a next step, we consider some of the determinants of time, cost, and efficiency of debt enforcement for our case facts. In table 2, countries are independently divided into three per capita income categories (high, upper-middle, and lower-middle income) and three categories based on the likely procedure to be used to enforce Mirage's debt (foreclosure, liquidation, and reorganization). Each of the nine groups lists the countries that fall into that group and for each country the time and cost of its procedure, the expected outcome (whether the firm continues as a going concern), the lending rate, and the summary efficiency measure. We also report the average for each income/procedure group, as well as the average of each variable by income group and by procedure.

The most basic findings of table 2 can be gleaned by looking at averages by procedure and by income. Countries are roughly evenly divided between those most likely to use foreclosure, liquidation, and reorganization to deal with Mirage, with reorganization a somewhat larger category than the other two. When we average across all countries using a particular procedure, there is no evidence that any procedure is always superior to others for our case facts. This is particularly interesting since, in our context, foreclosure in theory yields the first best. The question of appropriate debt enforcement rules cannot be resolved at such a broad level. 
TABLE 2

Data by Procedure and Income Group

\begin{tabular}{|c|c|c|c|c|c|}
\hline Country & Time & Cost $(\%)$ & $G C$ & Interest & Efficiency \\
\hline & \multicolumn{5}{|c|}{ A. High-INCOME GROUP } \\
\hline & \multicolumn{5}{|c|}{ Foreclosure } \\
\hline Singapore & .58 & 1 & 1 & 5.3 & 96.1 \\
\hline United Kingdom & .50 & 6 & 1 & 3.7 & 92.3 \\
\hline New Zealand & .67 & 4 & 1 & 9.8 & 90.7 \\
\hline Hong Kong, China & .63 & 9 & 1 & 5.0 & 88.3 \\
\hline Australia & .58 & 8 & 1 & 8.4 & 87.8 \\
\hline Kuwait & 4.00 & 1 & 0 & 5.4 & 55.9 \\
\hline Slovenia & 1.67 & 8 & 0 & 10.8 & 52.3 \\
\hline United Arab Emirates & 4.96 & 38 & 0 & 8.1 & 21.8 \\
\hline \multirow[t]{2}{*}{ Average } & 1.70 & 9 & .63 & 7.05 & 73.13 \\
\hline & \multicolumn{5}{|c|}{ Liquidation } \\
\hline Netherlands & 1.42 & 1 & 1 & 3.0 & 94.9 \\
\hline Sweden & 1.00 & 9 & 1 & 5.8 & 86.0 \\
\hline Austria & .92 & 18 & 1 & 5.6 & 78.0 \\
\hline Denmark & 2.50 & 9 & 1 & 7.1 & 76.7 \\
\hline Israel & 1.50 & 23 & 1 & 10.7 & 66.2 \\
\hline Germany & .92 & 8 & 0 & 9.7 & 57.0 \\
\hline Greece & 1.92 & 9 & 0 & 6.8 & 53.8 \\
\hline \multirow[t]{2}{*}{ Average } & 1.45 & 11 & .71 & 6.96 & 73.21 \\
\hline & \multicolumn{5}{|c|}{ Reorganization } \\
\hline Japan & .58 & 4 & 1 & 1.8 & 95.5 \\
\hline Taiwan, China & .83 & 4 & 1 & 3.4 & 93.8 \\
\hline Canada & .75 & 4 & 1 & 4.7 & 93.2 \\
\hline Finland & .92 & 4 & 1 & 4.8 & 92.4 \\
\hline Norway & .92 & 1 & 1 & 8.5 & 91.8 \\
\hline Belgium & .92 & 4 & 1 & 6.9 & 90.8 \\
\hline Ireland & .42 & 9 & 1 & 2.9 & 89.9 \\
\hline Korea, Republic & 1.50 & 4 & 1 & 6.2 & 88.1 \\
\hline United States & 2.00 & 7 & 1 & 4.1 & 85.8 \\
\hline Portugal & 2.00 & 9 & 1 & 5.2 & 82.3 \\
\hline Spain & 1.00 & 15 & 1 & 4.3 & 82.0 \\
\hline Puerto Rico & 3.79 & 8 & 1 & 4.7 & 77.4 \\
\hline Switzerland & 3.00 & 4 & 0 & 3.3 & 60.4 \\
\hline France & 1.89 & 9 & 0 & 6.6 & 54.1 \\
\hline Italy & 1.17 & 22 & 0 & 5.0 & 45.3 \\
\hline Average & 1.45 & 7 & .80 & 4.83 & 81.52 \\
\hline \multirow[t]{3}{*}{ High-income average } & 1.51 & 9 & .73 & 5.92 & 77.3 \\
\hline & \multicolumn{5}{|c|}{ B. UPPER-MiddLE INCOME } \\
\hline & \multicolumn{5}{|c|}{ Foreclosure } \\
\hline Oman & 2.75 & 4 & 0 & 8.2 & 53.5 \\
\hline Hungary & 1.88 & 15 & 0 & 9.6 & 46.7 \\
\hline Croatia & 1.92 & 15 & 0 & 11.6 & 45.0 \\
\hline Panama & 2.00 & 18 & 0 & 9.9 & 43.0 \\
\hline Chile & 5.08 & 15 & 0 & 6.2 & 40.9 \\
\hline Lebanon & 4.00 & 22 & 0 & 13.4 & 29.0 \\
\hline Uruguay & 1.92 & 7 & 0 & 50.9 & 28.6 \\
\hline Average & 2.79 & 13 & .00 & 15.70 & 40.97 \\
\hline
\end{tabular}


TABLE 2

(Continued)

\begin{tabular}{|c|c|c|c|c|c|}
\hline Country & Time & Cost $(\%)$ & $G C$ & Interest & Efficiency \\
\hline & \multicolumn{5}{|c|}{ Liquidation } \\
\hline Botswana & 1.33 & 15 & 1 & 16.6 & 69.7 \\
\hline Poland & 2.00 & 22 & 1 & 7.3 & 67.7 \\
\hline Slovak Republic & 4.08 & 18 & 1 & 8.5 & 58.9 \\
\hline Lithuania & 1.25 & 7 & 0 & 5.8 & 58.7 \\
\hline Estonia & 2.00 & 9 & 0 & 5.5 & 54.8 \\
\hline Latvia & 2.75 & 13 & 0 & 5.4 & 49.3 \\
\hline Malaysia & 2.25 & 15 & 0 & 6.3 & 48.4 \\
\hline Czech Republic & 6.00 & 15 & 0 & 5.3 & 40.7 \\
\hline Saudi Arabia & 2.71 & 22 & 0 & 6.4 & 40.6 \\
\hline Venezuela, RB & 3.96 & 38 & 0 & 25.2 & 13.1 \\
\hline \multirow[t]{2}{*}{ Average } & 2.83 & 17 & .30 & 9.23 & 50.20 \\
\hline & \multicolumn{5}{|c|}{ Reorganization } \\
\hline Mexico & 1.83 & 18 & 1 & 6.9 & 72.6 \\
\hline Argentina & 2.75 & 12 & 0 & 19.2 & 35.8 \\
\hline Costa Rica & 3.50 & 15 & 0 & 25.6 & 25.0 \\
\hline Average & 2.69 & 15 & .33 & 17.21 & 44.46 \\
\hline \multirow[t]{3}{*}{ Upper-middle-income average } & 2.80 & 16 & .20 & 12.69 & 46.1 \\
\hline & \multicolumn{5}{|c|}{ C. LOWER-MiddLe INCOME } \\
\hline & \multicolumn{5}{|c|}{ Foreclosure } \\
\hline Bosnia and Herzegovina & 1.83 & 9 & 1 & 10.3 & 76.1 \\
\hline Jamaica & 1.00 & 18 & 1 & 18.9 & 69.0 \\
\hline Armenia & 1.58 & 4 & 0 & 18.6 & 50.4 \\
\hline Sri Lanka & 1.42 & 18 & 0 & 9.5 & 45.7 \\
\hline China & 1.79 & 22 & 0 & 5.6 & 43.6 \\
\hline El Salvador & 3.67 & 9 & 0 & 14.0 & 37.8 \\
\hline Honduras & 2.88 & 8 & 0 & 19.9 & 36.8 \\
\hline Guatemala & 3.00 & 15 & 0 & 15.0 & 36.5 \\
\hline Georgia & 2.83 & 4 & 0 & 31.2 & 30.8 \\
\hline Paraguay & 3.92 & 9 & 0 & 50.0 & 12.5 \\
\hline \multirow[t]{2}{*}{ Average } & 2.39 & 12 & .20 & 19.29 & 43.90 \\
\hline & \multicolumn{5}{|c|}{ Liquidation } \\
\hline Jordan & 3.25 & 9 & 0 & 10.2 & 44.5 \\
\hline Albania & 3.50 & 38 & 1 & 11.8 & 42.0 \\
\hline South Africa & 1.92 & 18 & 0 & 15.0 & 39.8 \\
\hline Russian Federation & 3.67 & 9 & 0 & 13.0 & 39.0 \\
\hline Syrian Arab Republic & 5.42 & 9 & 0 & 9.0 & 38.2 \\
\hline Kazakhstan & 2.83 & 18 & 0 & 19.5 & 31.4 \\
\hline Egypt, Arab Republic & 4.08 & 22 & 0 & 13.5 & 28.6 \\
\hline Brazil & 3.67 & 12 & 1 & 67.1 & 13.4 \\
\hline Dominican Republic & 3.33 & 38 & 0 & 31.4 & 12.9 \\
\hline \multirow[t]{2}{*}{ Average } & 3.52 & 19 & .22 & 21.15 & 32.20 \\
\hline & \multicolumn{5}{|c|}{ Reorganization } \\
\hline Colombia & 3.00 & 1 & 1 & 15.2 & 64.8 \\
\hline Tunisia & 1.25 & 7 & 0 & 9.0 & 56.6 \\
\hline Thailand & 2.67 & 36 & 1 & 5.9 & 54.9 \\
\hline Algeria & 3.50 & 7 & 0 & 8.0 & 48.1 \\
\hline Bulgaria & 3.33 & 9 & 0 & 8.8 & 46.0 \\
\hline Namibia & 1.50 & 15 & 0 & 14.7 & 45.2 \\
\hline
\end{tabular}


TABLE 2

(Continued)

\begin{tabular}{lccccc}
\hline \hline Country & Time & Cost $(\%)$ & $G C$ & Interest & Efficiency \\
\hline Morocco & 1.83 & 18 & 0 & 12.6 & 41.9 \\
Peru & 3.08 & 7 & 0 & 14.2 & 41.8 \\
Iran, Islamic Republic & 4.50 & 9 & 0 & 17.5 & 29.5 \\
Serbia and Montenegro & 2.67 & 23 & 0 & 21.0 & 28.3 \\
Macedonia, former Yugoslav & & & & & \\
$\quad$ republic & 3.67 & 28 & 0 & 12.4 & 27.3 \\
Indonesia & 5.50 & 18 & 0 & 14.1 & 25.1 \\
Belarus & 5.75 & 22 & 0 & 16.9 & 19.5 \\
Ecuador & 8.00 & 18 & 0 & 13.1 & 19.4 \\
Ukraine & 2.92 & 42 & 0 & 17.4 & 17.5 \\
Philippines & 5.67 & 38 & 0 & 11.2 & 17.5 \\
Romania & 4.58 & 9 & 0 & 45.4 & 11.0 \\
Turkey & 5.88 & 7 & 0 & 46.7 & 6.6 \\
Angola & 6.17 & 22 & 0 & 82.3 & 1.2 \\
Average & 3.97 & 18 & .11 & 20.34 & 31.70 \\
Lower-middle-income average & 3.45 & 16 & .16 & 20.257 & 35.0 \\
Average by procedure: & & & & & \\
$\quad$ Foreclosure & 2.28 & 11 & .28 & 14.37 & 52.44 \\
$\quad$ Liquidation & 2.70 & 16 & .38 & 12.74 & 50.16 \\
$\quad$ Reorganization & 2.84 & 13 & .41 & 13.80 & 52.93 \\
\hline
\end{tabular}

NoTE. - The table presents country data organized by both income and the debt enforcement procedure that applies in the case. For each country the table shows the time and cost of debt enforcement proceedings, an indicator of whether Mirage is expected to continue as a going concern, the lending rate, and the efficiency of debt enforcement. Table 1 describes the variables in detail.

If we compare income groups, in contrast, enormous differences emerge. The richer countries are vastly more efficient at debt enforcement than the poorer ones. If we average over all the procedures, the richest countries take 1.5 years to resolve debt enforcement, at a transaction cost of 9 percent of the estate. They preserve Mirage as a going concern in 73 percent of the cases, have an average interest rate of 5.9 percent, and achieve the average efficiency score of 77.3. The corresponding numbers for upper-middle-income countries are 2.80 years, 16 percent of the estate, only 20 percent of the cases preserving Mirage as a going concern, an interest rate of 12.7 percent, and the average efficiency score of 46.1. For the lower-middle-income countries the time is 3.45 years, the cost is again 16 percent, the going concern outcome also materializes in 16 percent of the cases, the interest rate is 20.3 percent, and the efficiency score is 35 on average. The decline in the efficiency score compared to upper-middle-income countries comes from higher interest rates and longer delays in the lower-middle-income countries. Clearly, per capita income is a crucial determinant both of getting the right outcome and of the overall efficiency of debt enforcement.

There are several potential reasons for the fourfold difference between the rich and the middle-income countries in efficiently preserving 
Mirage as a going concern. One possibility is the difference in administrative or judicial competence, which causes lower-middle-income countries to nearly always fail at rehabilitation (Ayotte and Yun 2009). Alternatively, successful rehabilitation may require a good deal of security of Bizbank's property rights, which cannot be guaranteed in middle-income countries (Gennaioli and Rossi 2007). If suppliers, customers, employees, management, or Mr. Douglas can lay claims on Mirage's assets during rehabilitation (or even tunnel them), Bizbank has a very strong incentive to grab what it can and sell it piecemeal.

Per capita income does not explain everything, however. Some rich countries, such as United Arab Emirates and Italy, have hugely inefficient debt enforcement. Some lower-middle-income countries, such as Bosnia, Jamaica, and Colombia, do pretty well. Nonetheless, debt enforcement joins the list of many other public, as well as private, activities in which per capita income predicts efficiency.

Per capita income is a strong predictor of both the going concern outcome and efficiency for every procedure. The rich countries are the most efficient at foreclosure, liquidation, and reorganization; the uppermiddle-income countries are roughly as efficient as the lower-middleincome ones at foreclosure and reorganization and sharply more efficient at liquidation. The basic finding is not a procedure composition effect.

A closer look reveals an interesting pattern in table 2. Among highincome countries, foreclosure is roughly as efficient as liquidation, but reorganization is the most efficient procedure. The main reason is that reorganization preserves Mirage as a going concern 80 percent of the time, compared to 63 percent for foreclosure and 71 percent for liquidation. Among the lower-middle-income countries, reorganization is roughly as efficient as liquidation, but foreclosure is the most efficient procedure. These countries rarely manage to save Mirage as a going concern, so speed and lower cost are conducive to efficiency. For uppermiddle-income countries, the most efficient procedure is liquidation. Overall, the richer countries are doing better at procedures involving higher levels of court intervention.

Table 3 presents the same data as table 2, except countries are organized by procedure and legal origin rather than procedure and per capita income. Several results stand out. First, relative to general world patterns, French legal origin countries rely particularly heavily on reorganization of Mirage and German legal origin countries on liquidation-the latter being a familiar result. None of the four Nordic countries utilizes foreclosure. The Nordic countries achieve very high efficiency, largely because they always succeed in keeping Mirage as a going concern (and are very fast). Some of this efficiency undoubtedly comes from being rich. 
TABLE 3

Data by Procedure and Legal Origin

\begin{tabular}{|c|c|c|c|c|c|}
\hline Country & Time & Cost $(\%)$ & $G C$ & Interest & Efficiency \\
\hline & \multicolumn{5}{|c|}{ A. Common Law } \\
\hline & \multicolumn{5}{|c|}{ Foreclosure } \\
\hline Singapore & .58 & 1 & 1 & 5.3 & 96.1 \\
\hline United Kingdom & .50 & 6 & 1 & 3.7 & 92.3 \\
\hline New Zealand & .67 & 4 & 1 & 9.8 & 90.7 \\
\hline Hong Kong, China & .63 & 9 & 1 & 5.0 & 88.3 \\
\hline Australia & .58 & 8 & 1 & 8.4 & 87.8 \\
\hline Jamaica & 1.00 & 18 & 1 & 18.9 & 69.0 \\
\hline Sri Lanka & 1.42 & 18 & 0 & 9.5 & 45.7 \\
\hline \multirow[t]{2}{*}{ Average } & .77 & 9 & .86 & 8.65 & 81.40 \\
\hline & \multicolumn{5}{|c|}{ Liquidation } \\
\hline Botswana & 1.33 & 15 & 1 & 16.6 & 69.7 \\
\hline Israel & 1.50 & 23 & 1 & 10.7 & 66.2 \\
\hline Malaysia & 2.25 & 15 & 0 & 6.3 & 48.4 \\
\hline South Africa & 1.92 & 18 & 0 & 15.0 & 39.8 \\
\hline \multirow[t]{2}{*}{ Average } & 1.75 & 18 & .50 & 12.12 & 56.01 \\
\hline & \multicolumn{5}{|c|}{ Reorganization } \\
\hline Japan & .58 & 4 & 1 & 1.8 & 95.5 \\
\hline Canada & .75 & 4 & 1 & 4.7 & 93.2 \\
\hline Ireland & .42 & 9 & 1 & 2.9 & 89.9 \\
\hline Korea, Republic & 1.50 & 4 & 1 & 6.2 & 88.1 \\
\hline United States & 2.00 & 7 & 1 & 4.1 & 85.8 \\
\hline Puerto Rico & 3.79 & 8 & 1 & 4.7 & 77.4 \\
\hline Thailand & 2.67 & 36 & 1 & 5.9 & 54.9 \\
\hline Namibia & 1.50 & 15 & 0 & 14.7 & 45.2 \\
\hline Philippines & 5.67 & 38 & 0 & 11.2 & 17.5 \\
\hline Average & 2.10 & 14 & .78 & 6.25 & 71.95 \\
\hline \multirow[t]{3}{*}{ Common law average } & 1.56 & 13 & .75 & 8.3 & 72.1 \\
\hline & \multicolumn{5}{|c|}{ B. French Legal Origin } \\
\hline & \multicolumn{5}{|c|}{ Foreclosure } \\
\hline Kuwait & 4.00 & 1 & 0 & 5.4 & 55.9 \\
\hline Oman & 2.75 & 4 & 0 & 8.2 & 53.5 \\
\hline Panama & 2.00 & 18 & 0 & 9.9 & 43.0 \\
\hline Chile & 5.08 & 15 & 0 & 6.2 & 40.9 \\
\hline El Salvador & 3.67 & 9 & 0 & 14.0 & 37.8 \\
\hline Honduras & 2.88 & 8 & 0 & 19.9 & 36.8 \\
\hline Guatemala & 3.00 & 15 & 0 & 15.0 & 36.5 \\
\hline Lebanon & 4.00 & 22 & 0 & 13.4 & 29.0 \\
\hline Uruguay & 1.92 & 7 & 0 & 50.9 & 28.6 \\
\hline United Arab Emirates & 4.96 & 38 & 0 & 8.1 & 21.8 \\
\hline Paraguay & 3.92 & 9 & 0 & 50.0 & 12.5 \\
\hline \multirow[t]{2}{*}{ Average } & 3.47 & 13 & .00 & 18.27 & 36.03 \\
\hline & \multicolumn{5}{|c|}{ Liquidation } \\
\hline Netherlands & 1.42 & 1 & 1 & 3.0 & 94.9 \\
\hline Greece & 1.92 & 9 & 0 & 6.8 & 53.8 \\
\hline Jordan & 3.25 & 9 & 0 & 10.2 & 44.5 \\
\hline Saudi Arabia & 2.71 & 22 & 0 & 6.4 & 40.6 \\
\hline Russian Federation & 3.67 & 9 & 0 & 13.0 & 39.0 \\
\hline Syrian Arab Republic & 5.42 & 9 & 0 & 9.0 & 38.2 \\
\hline
\end{tabular}


TABLE 3

(Continued)

\begin{tabular}{|c|c|c|c|c|c|}
\hline Country & Time & Cost $(\%)$ & $G C$ & Interest & Efficiency \\
\hline Egypt, Arab Republic & 4.08 & 22 & 0 & 13.5 & 28.6 \\
\hline Brazil & 3.67 & 12 & 1 & 67.1 & 13.4 \\
\hline Venezuela, RB & 3.96 & 38 & 0 & 25.2 & 13.1 \\
\hline Dominican Republic & 3.33 & 38 & 0 & 31.4 & 12.9 \\
\hline \multirow[t]{2}{*}{ Average } & 3.34 & 17 & .20 & 18.55 & 37.91 \\
\hline & \multicolumn{5}{|c|}{ Reorganization } \\
\hline Belgium & .92 & 4 & 1 & 6.9 & 90.8 \\
\hline Portugal & 2.00 & 9 & 1 & 5.2 & 82.3 \\
\hline Spain & 1.00 & 15 & 1 & 4.3 & 82.0 \\
\hline Mexico & 1.83 & 18 & 1 & 6.9 & 72.6 \\
\hline Colombia & 3.00 & 1 & 1 & 15.2 & 64.8 \\
\hline Switzerland & 3.00 & 4 & 0 & 3.3 & 60.4 \\
\hline Tunisia & 1.25 & 7 & 0 & 9.0 & 56.6 \\
\hline France & 1.89 & 9 & 0 & 6.6 & 54.1 \\
\hline Algeria & 3.50 & 7 & 0 & 8.0 & 48.1 \\
\hline Bulgaria & 3.33 & 9 & 0 & 8.8 & 46.0 \\
\hline Italy & 1.17 & 22 & 0 & 5.0 & 45.3 \\
\hline Morocco & 1.83 & 18 & 0 & 12.6 & 41.9 \\
\hline Peru & 3.08 & 7 & 0 & 14.2 & 41.8 \\
\hline Argentina & 2.75 & 12 & 0 & 19.2 & 35.8 \\
\hline Iran, Islamic Republic & 4.50 & 9 & 0 & 17.5 & 29.5 \\
\hline Indonesia & 5.50 & 18 & 0 & 14.1 & 25.1 \\
\hline Costa Rica & 3.50 & 15 & 0 & 25.6 & 25.0 \\
\hline Belarus & 5.75 & 22 & 0 & 16.9 & 19.5 \\
\hline Ecuador & 8.00 & 18 & 0 & 13.1 & 19.4 \\
\hline Romania & 4.58 & 9 & 0 & 45.4 & 11.0 \\
\hline Turkey & 5.88 & 7 & 0 & 46.7 & 6.6 \\
\hline Angola & 6.17 & 22 & 0 & 82.3 & 1.2 \\
\hline Average & 3.38 & 12 & .23 & 17.58 & 43.63 \\
\hline \multirow[t]{3}{*}{ French legal origin average } & 3.40 & 13 & .16 & 18.0 & 40.4 \\
\hline & \multicolumn{5}{|c|}{ C. German Legal Origin } \\
\hline & \multicolumn{5}{|c|}{ Foreclosure } \\
\hline Bosnia and Herzegovina & 1.83 & 9 & 1 & 10.3 & 76.1 \\
\hline Slovenia & 1.67 & 8 & 0 & 10.8 & 52.3 \\
\hline Armenia & 1.58 & 4 & 0 & 18.6 & 50.4 \\
\hline Hungary & 1.88 & 15 & 0 & 9.6 & 46.7 \\
\hline Croatia & 1.92 & 15 & 0 & 11.6 & 45.0 \\
\hline China & 1.79 & 22 & 0 & 5.6 & 43.6 \\
\hline Georgia & 2.83 & 4 & 0 & 31.2 & 30.8 \\
\hline \multirow[t]{2}{*}{ Average } & 1.93 & 11 & .14 & 13.95 & 49.25 \\
\hline & \multicolumn{5}{|c|}{ Liquidation } \\
\hline Austria & .92 & 18 & 1 & 5.6 & 78.0 \\
\hline Poland & 2.00 & 22 & 1 & 7.3 & 67.7 \\
\hline Slovak Republic & 4.08 & 18 & 1 & 8.5 & 58.9 \\
\hline Lithuania & 1.25 & 7 & 0 & 5.8 & 58.7 \\
\hline Germany & .92 & 8 & 0 & 9.7 & 57.0 \\
\hline Estonia & 2.00 & 9 & 0 & 5.5 & 54.8 \\
\hline Latvia & 2.75 & 13 & 0 & 5.4 & 49.3 \\
\hline Albania & 3.50 & 38 & 1 & 11.8 & 42.0 \\
\hline Czech Republic & 6.00 & 15 & 0 & 5.3 & 40.7 \\
\hline Kazakhstan & 2.83 & 18 & 0 & 19.5 & 31.4 \\
\hline & & & & & \\
\hline
\end{tabular}


TABLE 3

(Continued)

\begin{tabular}{|c|c|c|c|c|c|}
\hline Country & Time & Cost $(\%)$ & $G C$ & Interest & Efficiency \\
\hline \multirow[t]{2}{*}{ Average } & 2.63 & 17 & .40 & 8.44 & 53.85 \\
\hline & \multicolumn{5}{|c|}{ Reorganization } \\
\hline Taiwan, China & .83 & 4 & 1 & 3.4 & 93.8 \\
\hline Serbia and Montenegro & 2.67 & 23 & 0 & 21.0 & 28.3 \\
\hline Macedonia, former Yugoslav & & & & & \\
\hline $\begin{array}{l}\text { republic } \\
\text { Ukraine }\end{array}$ & 3.67 & 28 & 0 & 12.4 & 27.3 \\
\hline Ukraine & 2.92 & 42 & 0 & 17.4 & 17.5 \\
\hline Average & 2.52 & 24 & .25 & 13.56 & 41.74 \\
\hline \multirow[t]{3}{*}{ German legal origin average } & 2.37 & 16 & .29 & 11.3 & 50.0 \\
\hline & \multicolumn{5}{|c|}{ D. Nordic Legal Origin } \\
\hline & \multicolumn{5}{|c|}{ Foreclosure } \\
\hline \multicolumn{6}{|l|}{ None } \\
\hline & \multicolumn{5}{|c|}{ Liquidation } \\
\hline Sweden & 1.00 & 9 & 1 & 5.8 & 86.0 \\
\hline Denmark & 2.50 & 9 & 1 & 7.1 & 76.7 \\
\hline \multirow[t]{2}{*}{ Average } & 1.75 & 9 & 1.00 & 6.46 & 81.33 \\
\hline & \multicolumn{5}{|c|}{ Reorganization } \\
\hline Finland & .92 & 4 & 1 & 4.8 & 92.4 \\
\hline Norway & .92 & 1 & 1 & 8.5 & 91.8 \\
\hline Average & .92 & 2 & 1.00 & 6.68 & 92.13 \\
\hline Nordic legal origin average & 1.33 & 6 & 1.00 & 6.6 & 86.7 \\
\hline
\end{tabular}

Note. - The table presents country data organized by both the country's legal origin and the debt enforcement procedure that applies in the case. For each country the table shows the time and cost of debt enforcement proceedings, an indicator of whether Mirage will continue as a going concern, the lending rate, and the efficiency of debt enforcement. Table 1 describes the variables in detail.

When we average across procedures, common law countries achieve sharply higher efficiency scores than either German or French legal origin countries in their debt enforcement. Part of this comes from their having lower interest rates than the German, and particularly the French, legal origin countries. The German legal origin countries are more efficient than the French ones in foreclosure and liquidation but are slightly behind in reorganization. The common law countries are more efficient than French and German legal origin ones at all procedures, although they are only slightly ahead of German legal origin countries in liquidation. The latter have a comparative advantage at liquidation; the common law countries have a comparative advantage at foreclosure.

The immediate reason for the low efficiency of French legal origin countries in debt enforcement is clear from the data: whatever procedure they use, they succeed in keeping Mirage as a going concern in only 16 percent of the cases. The comparable number for common law countries is 75 percent. The failure to keep Mirage going is not just a 
poor country outcome; both France and Italy fail to do so, according to our respondents. Related to this failed effort to rehabilitate, it takes French legal origin countries 3.40 years to resolve debt enforcement, compared to 1.56 years for common law countries. There is no difference in the transaction costs of the procedures. These results present a clear finding but also a puzzle: why do French legal origin countries take so long but still fail to keep Mirage going? We try to shed light on this question in Section VI.

The results of tables 2 and 3 are summarized compactly in table 4, which presents cross-country ordinary least squares regressions. In columns 1-3, the dependent variable is the efficiency of debt enforcement procedure; in columns $4-6$, the dependent variable is $G C$; and in columns 7-9, it is Bizbank's recovery rate (see Sec. V). The independent variables include, depending on the specification, the logarithm of per capita GDP, legal origin, procedure types (with common law and foreclosure omitted), and interaction terms of procedure type and per capita income.

The results confirm that richer countries have sharply higher efficiency scores and are more likely to keep Mirage as a going concern. Compared to common law countries, French and German legal origin countries are sharply less efficient; Nordic countries are less efficient when income is held constant, but this result is not statistically significant. There are no statistically significant differences among procedures in either efficiency or keeping Mirage as a going concern, except in the third regression the coefficient on reorganization is sharply negative and statistically significant. Looking at the interaction terms, we do find support for the idea that reorganization is relatively more efficient in richer countries, but there are no statistically significant differences between foreclosure and liquidation. These results are supportive of the findings in tables 2 and 3, except the conclusions about the comparative advantage of alternative procedures are moderated.

We have reestimated the regressions in table 4 using an 8 percent discount rate for all countries to calculate efficiency, as well as by using a probit when the dependent variable is $G C$. The results for per capita income and legal origins are robust to these changes.

Before moving on, we revisit two assumptions made in the calculation of efficiency. First, we assumed that the costs of going through insolvency are paid at the end and hence are discounted back from the time insolvency is resolved in the computation of efficiency. We can alternatively assume that these costs are incurred up-front and are therefore not discounted at all. This simple correction obviously reduces the efficiency measure. The worldwide average efficiency drops to 47.85 (about 4 points), although efficiency for the lower-middle-income countries falls all the way to 28.5. A few countries, such as Venezuela and 


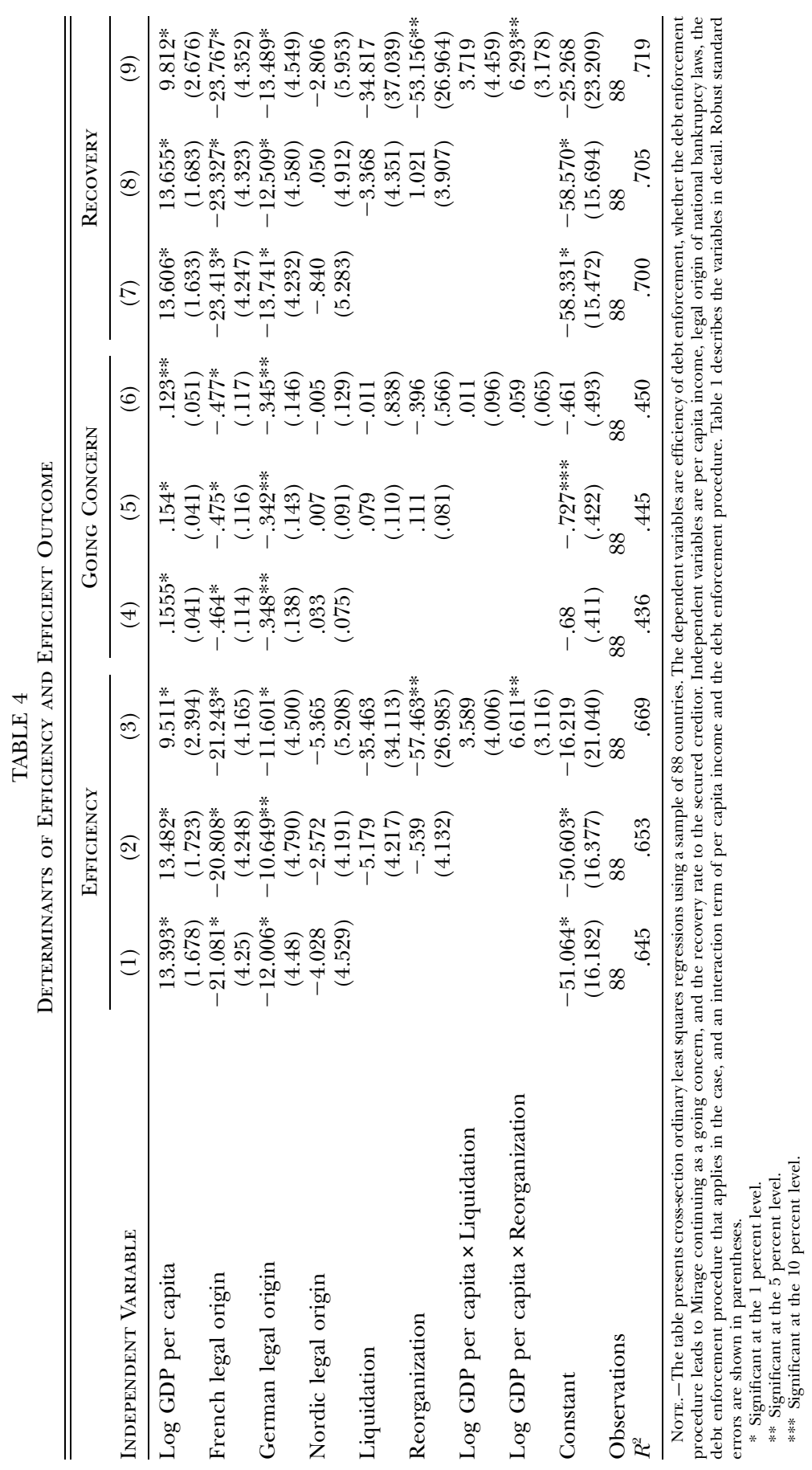


Angola, now have negative efficiency scores due to the implausibly extreme front-loading of the transaction costs. The basic orderings documented in tables 2 and 3, as well as the result that richer countries have a comparative advantage in more complex procedures, are preserved.

The second assumption we made is that Mirage just covers its variable costs while in bankruptcy and generates no economic value. We can be more optimistic about profitability in bankruptcy even if we maintain, as we have advised the respondents, that the firm does not generate enough cash to pay back its debt. For example, we can assume that while the proceedings are going on, Mirage generates profits at the same rate as it does once the proceedings are completed, that is, at the rate that justifies its ultimate valuation. That assumption means that in the countries in which Mirage remains a going concern, it generates sufficient profits to justify the valuation of 100 even when in bankruptcy, which implies that the delay associated with bankruptcy has zero cost. We think that this is implausibly optimistic. ${ }^{7}$ Alternatively, we can assume that while Mirage is in the insolvency proceedings, it generates enough cash to yield the valuation of 70 (even if it is eventually preserved as a going concern). This is better than generating no profits but not as good as if bankruptcy were not costly at all.

The assumption that Mirage generates its piecemeal sale value in bankruptcy yields the following definition of efficiency:

$$
E=70+\frac{30 \times G C-100 \times c}{(1+r)^{t}} .
$$

Under this definition, the worldwide average efficiency measure rises to 69.6 and to 63.1 for the lower-middle-income countries. Efficiency now basically reflects the cost of liquidating Mirage piecemeal rather than keeping it as a going concern. Lower-middle-income countries almost never manage to keep Mirage as a going concern, so the only cost of insolvency is the (discounted) transaction cost. We feel that this view is too optimistic, so we prefer our initial measure of efficiency. Nonetheless, the orderings of efficiency measures reported in tables 2 and 3 are preserved under this specification, except that the result that rich countries have a comparative advantage at the more complex procedures is no longer statistically significant.

\footnotetext{
${ }^{7}$ Gamboa-Cavazos and Schneider (2006), in their detailed study of Mexican bankruptcies, find that a tremendous amount of value is lost during the proceedings, leading to extremely low recovery rates for creditors.
} 


\section{Absolute Priority}

An important aspect of debt enforcement is violation of absolute priority. In the United States, such violations result from bankruptcy judges disregarding debt contracts (Franks and Torous 1989; Weiss and Wruck 1998). In other countries, the law sometimes gives other claimants priority over the secured creditors. For example, tax authorities, employees, suppliers, or even shareholders may by law have priority over Bizbank in their claims against Mirage. Such violations of absolute priority may distort Bizbank's incentive to dispose of Mirage most efficiently and have adverse consequences for the development of debt markets. La Porta et al. $(1997,1998)$ use violation of absolute priority by law as an element of their creditor rights index. Our respondents provided information on deviations from absolute priority in their countries' laws, and here we examine these patterns. We use these data to examine an alternative measure of quality of debt enforcement: the payoff to Bizbank rather than overall efficiency.

The raw facts on deviations from absolute priority are striking. In the world as a whole, 55 percent of countries deviate from absolute priority and only 45 percent respect it. Deviations from absolute priority occur in 33 percent of high-income countries, 50 percent of upper-middleincome countries, and 74 percent of lower-middle-income countries. They occur in no Nordic countries, 25 percent of English legal origin countries, 52 percent of German legal origin countries, and 74 percent of French legal origin countries. In this particular obstacle to debt enforcement, the poor and the French legal origin countries again lead the way.

For a more detailed analysis, we record the order of priority, $P$, in which claims are paid. If Bizbank, the secured creditor, is paid first out of the proceeds from the insolvency proceeding, then $P=1$. If one claimant group - the tax authority, workers, suppliers, or shareholdershas priority over the secured creditor, ranking Bizbank second in priority, then $P=2$. If the secured creditor is ranked third after two other claimant groups, $P=3$; if it is ranked fourth, $P=4$. One additional change is that, to compute Bizbank's recovery, the relevant time is no longer the time to resolve what happens with Mirage, but rather the time it takes Bizbank to get paid, which we defined as time to payment. The recovery rate for the secured creditor is then given by

$$
R=\frac{100 \times G C+70 \times(1-G C)-12 \times(P-1)-100 \times c}{(1+r)^{t}} .
$$

The worldwide mean of the priority variable is 1.9 . Time to payment is on average about 3 months longer than time to resolution, although the difference exceeds 2 years for Israel and the Czech Republic. The 
worldwide mean of Bizbank's recovery is 45 percent, compared to the mean 52 percent for the efficiency measure. In other words, an additional 7 percent of the estate is lost to the senior creditor, on average, because of violations of absolute priority. The correlation between priority and recovery is $-.52 .{ }^{8}$ Furthermore, the correlation between the efficiency of debt enforcement and Bizbank's recovery rate is .96. Not surprisingly, the empirical correlates of the recovery rate are essentially the same as those of efficiency. Most important, per capita income and legal origin crucially shape both. The average recovery rate is 67 percent for common law countries, 33 percent for French legal origin countries, 43 percent for German legal origin countries, and 85 percent for Nordic countries. The last three regressions in table 4 confirm these patterns. ${ }^{9}$ These results suggest that national priority rules undermine debt enforcement even relative to the dire situation that would exist if priority were respected, especially in the lower-middle-income and French legal origin countries.

\section{Structural Characteristics of Debt Enforcement}

The results of Section IV suggest that the efficiency of debt enforcement is shaped by per capita income and legal origin-two variables that cannot be quickly changed. In this section, we look instead at a number of structural characteristics of debt enforcement procedures and ask whether they explain efficiency and its determinants. We also ask whether such explanatory power remains even when per capita income and legal origin are held constant. This may be too tough a test since, as we show below, many structural characteristics of debt enforcement are correlated with per capita income and especially legal origin. Nonetheless, some tentative suggestions for improving debt enforcement procedure may emerge as a result.

Panel B of table 1 presents the 24 structural characteristics of debt enforcement obtained from our respondents. We divide these characteristics into five groups: those that pertain to all procedures (there is only one of those), those that pertain to foreclosure only, those that pertain to all bankruptcy procedures (i.e., liquidation and reorganization), those that pertain to liquidation only, and those that pertain to

\footnotetext{
${ }^{8}$ Davydenko and Frank (2008) estimate median bank recovery rates for samples of actual bankruptcies in the United Kingdom, Germany, and France. Their estimates are 92 percent, 67 percent, and 56 percent, respectively, which is not too far from our estimates of 91 percent, 56 percent, and 47 percent for the respective countries.

${ }^{9}$ The structural variables discussed in Sec. VI that are correlated with efficiency are also highly correlated with recovery.
} 
reorganization only. These measures include both economic and legal characteristics of debt enforcement. ${ }^{10}$

Table 5 presents the frequencies of these characteristics by legal origin, and table 6 shows their correlations with the logarithm of per capita income, the civil law dummy, and outcomes. We discuss the results by procedure of relevance. Table 7 shows regressions of efficiency on legal origins, per capita income, and each of the structural variables taken one at a time, organized again by procedure of relevance. We focus on the results in tables 5 and 6 but also indicate whether they are robust to table 7 specifications.

The only variable that applies to all procedures is the presence of statutory time limits on appeals. These limits tend to be present in poorer countries and are negatively correlated with both keeping Mirage as a going concern and efficiency. This negative correlation disappears once income is controlled for in table 7 .

The next three variables pertain to foreclosure. The first twowhether Bizbank is allowed the out-of-court seizure and sale of collateral and whether Bizbank is allowed to enforce its claim in an out-of-court procedure-are measures of raw creditor power in foreclosure. Both variables are characteristic of common law foreclosure (table 5) and are strongly associated with a shorter time to complete foreclosure, greater likelihood of keeping Mirage as a going concern, and higher overall efficiency (table 6). The third variable, floating charge, measures whether Bizbank can by law take the whole of Mirage, as opposed to specific fixed assets, as collateral. This variable too is a characteristic of common law legal regimes (table 5) and is associated with shorter time, lower cost, a higher likelihood that Mirage is kept going, and higher overall efficiency (table 6). The common law way of doing foreclosure, which allows floating charge debt contracts and gives the senior creditor enormous rights without much protection of Mirage from courts, works very well for our case facts.

These results may shed light on a puzzling feature of the data. Recall that, under our case assumptions, Bizbank has the socially optimal incentives to deal with Mirage if it can control it after the default. Why is it, then, that in table 2, for both the rich and upper-middle-income countries, liquidation and reorganization yield higher efficiency than foreclosure? Tables 5 and 6 suggest a possible explanation: legal restrictions on floating charge debt, which undermine Bizbank's ability to take control of Mirage. This hypothesis has received some attention in recent legal literature (e.g., Armour 2007).

To test this hypothesis, we present in table 8 separately the average

\footnotetext{
${ }^{10}$ Our data for the structural characteristics are almost but not entirely complete, in that we did not obtain usable information for some of the countries from our respondents.
} 
efficiency of foreclosure for countries with and without floating charge. Our findings are consistent with this hypothesis. In every income category, the average efficiency of foreclosure with floating charge is higher than that of both liquidation and reorganization. Under our case facts, floating charge foreclosure indeed comes closest to efficiency, although one must be careful to note that these results might reflect some other benefit of common law. These results are also broadly consistent with Franks and Sussman's (2005) optimistic empirical assessment of foreclosure with floating charge in the United Kingdom.

The next round of variables deals with characteristics of bankruptcy procedures. The first variable-whether bankruptcy is handled by a specialized court-shows that such courts are sharply more prevalent in the richer and in the common law countries. The handling of bankruptcy by a specialized court is associated with lower case time, lower cost, a higher likelihood that Mirage continues as a going concern, and a sharply higher measure of overall efficiency. This result, however, does not survive in table 7 .

The next six variables deal with specific aspects of the appeal process of bankruptcy proceedings. Three of them measure whether the case proceeds while particular appeals are made; these variables directly capture the scope for delay. Three parallel variables measure whether appeals are heard by the same judge as the one issuing the initial order or by a different judge. These variables also measure the scope for delay, although less directly. Appeal variables are not strongly related to per capita income or legal origin (with the exception of one "same judge" variable). We see, however, that having the bankruptcy case proceed (rather than be suspended) while particular rulings are appealed is strongly related to shorter time and higher overall efficiency. In contrast, having appeals heard by the same judge does not seem to influence time or efficiency. Interestingly, in the regression specifications of table 6 , both types of appeals variables matter for efficiency. ${ }^{11}$

The next variable captures the legal requirement that reorganization be attempted before Mirage goes into liquidation. This requirement is more prevalent in poorer and in civil law countries and is associated with a lower probability that Mirage continues as a going concern and lower efficiency (but not in the regression). The next variable, automatic stay, measures whether Bizbank is prevented from enforcing its security when bankruptcy proceedings commence. It is not correlated with our outcome measures. Automatic stay on lawsuits measures whether lawsuits

${ }^{11}$ This finding is broadly consistent with Gamboa-Cavazos and Schneider's (2006) study of bankruptcy reform in Mexico, which finds that much of its benefits in terms of faster resolution of bankruptcy and higher recovery rates for creditors derived from the curtailment of appeals. 


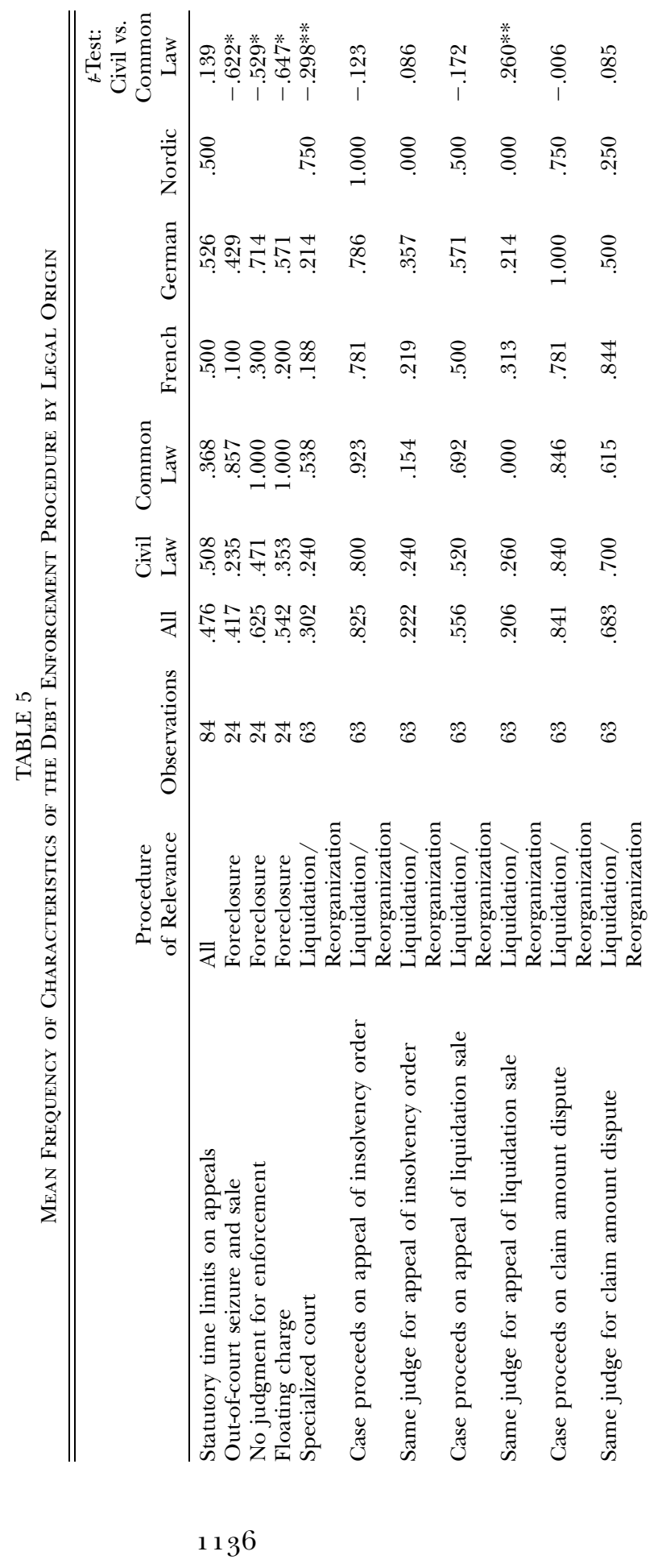




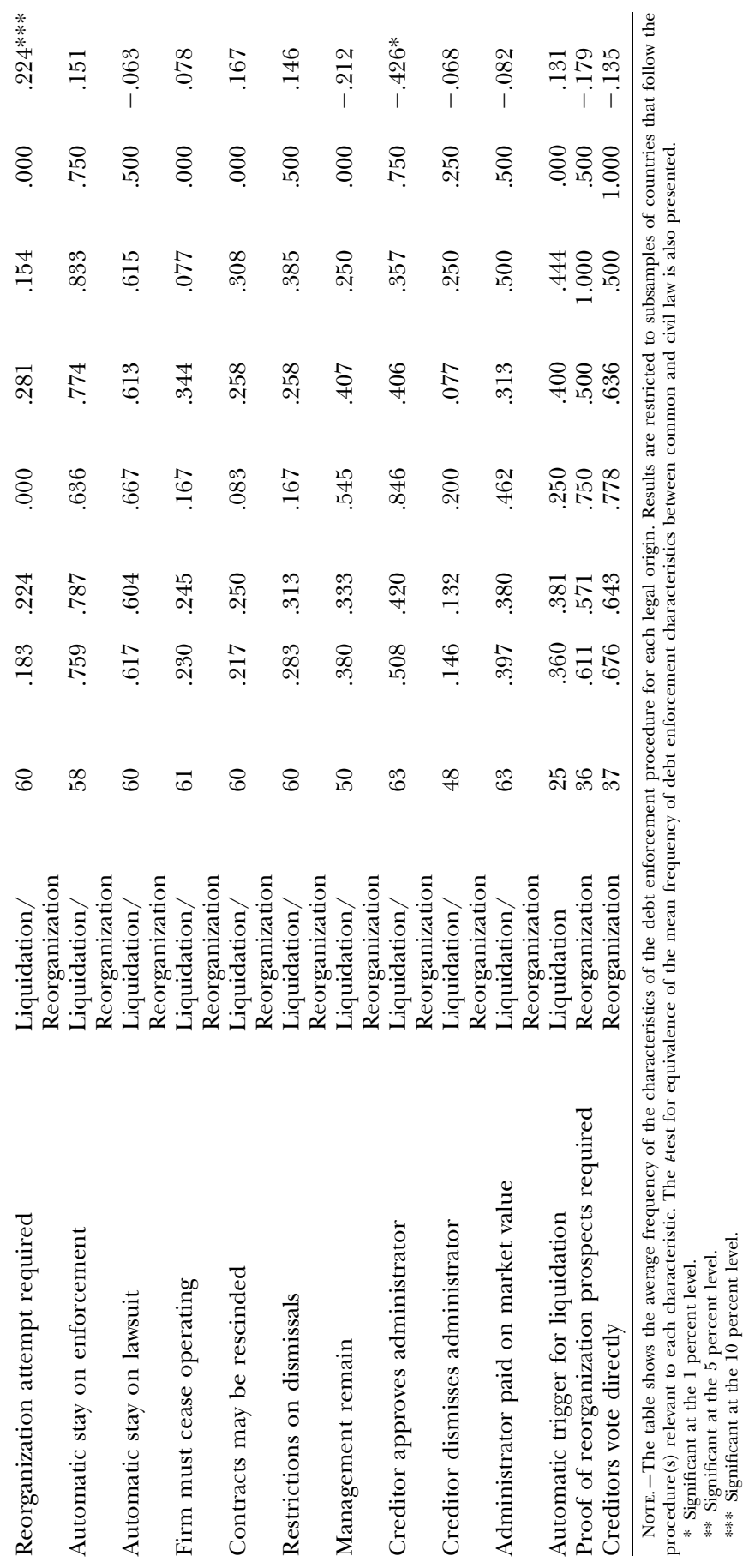

1137 


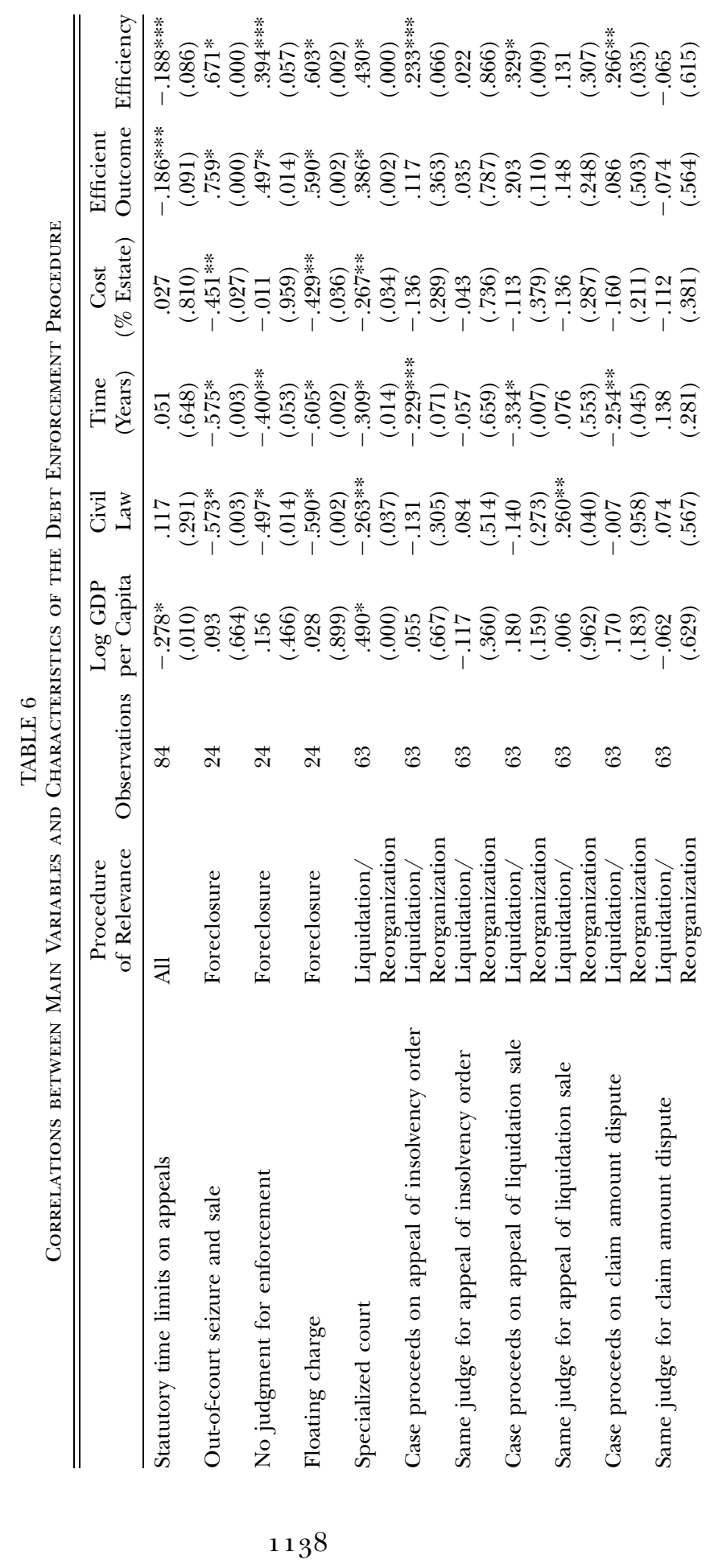




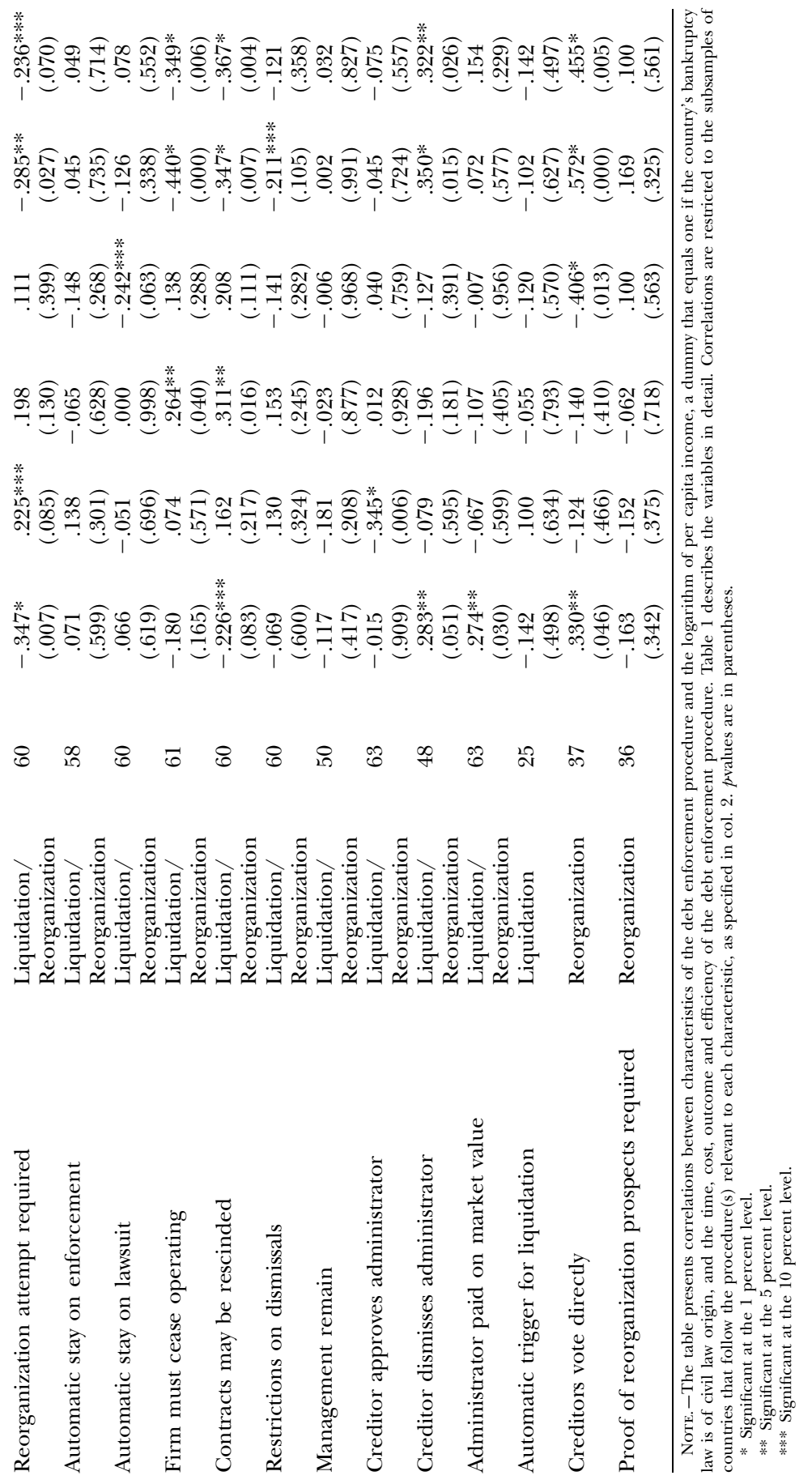

1139 


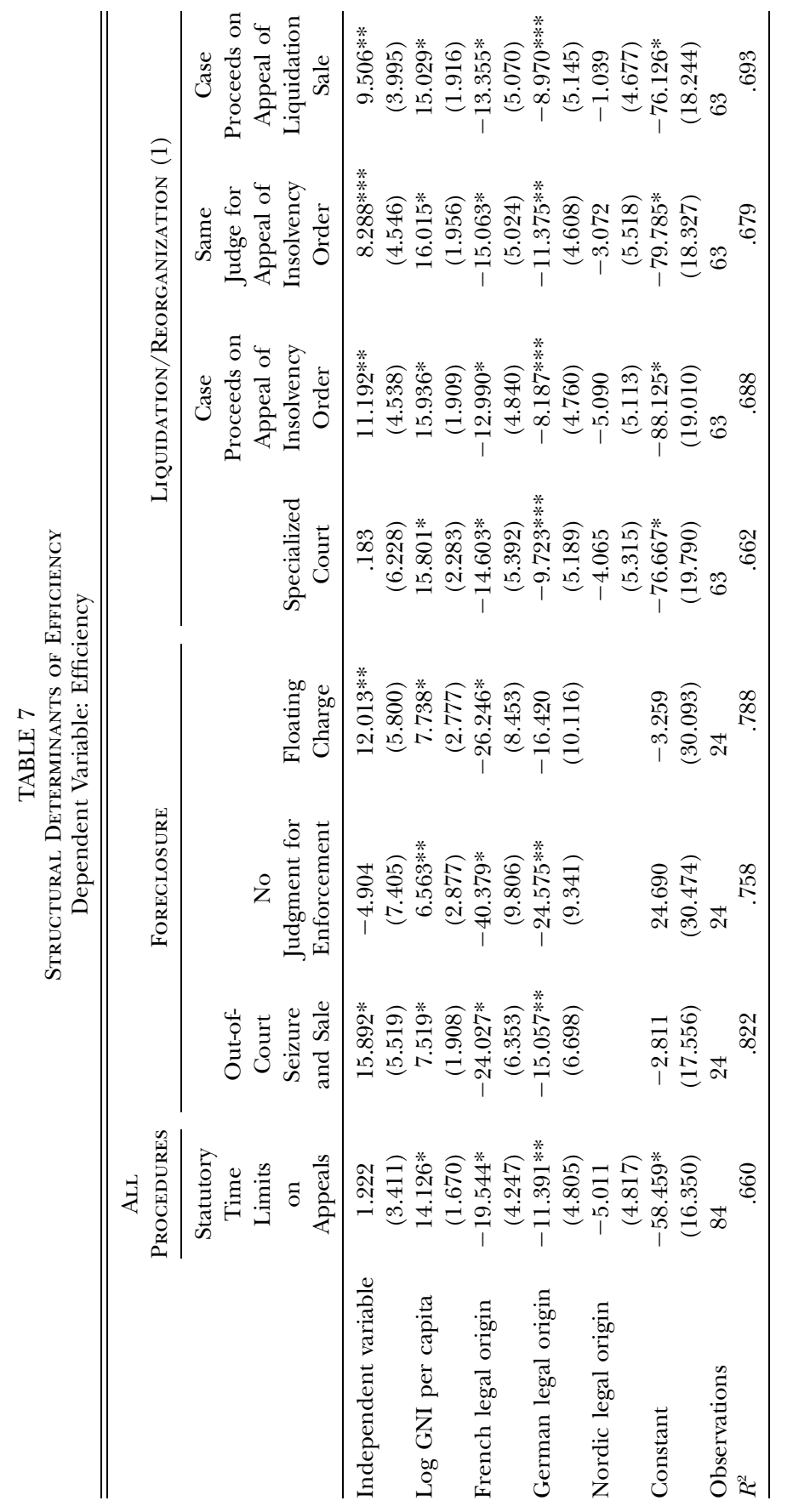

$114^{\circ}$ 


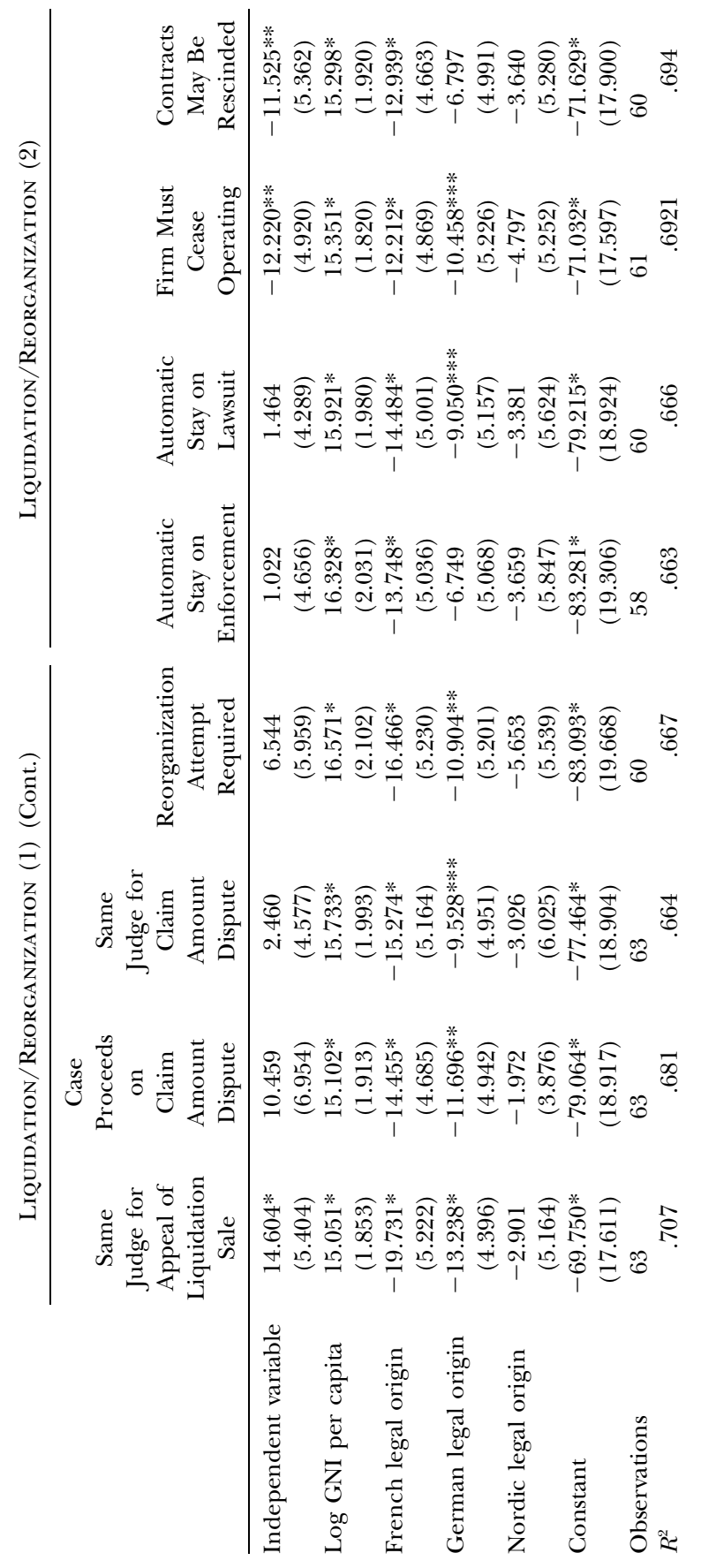

$114^{1}$ 


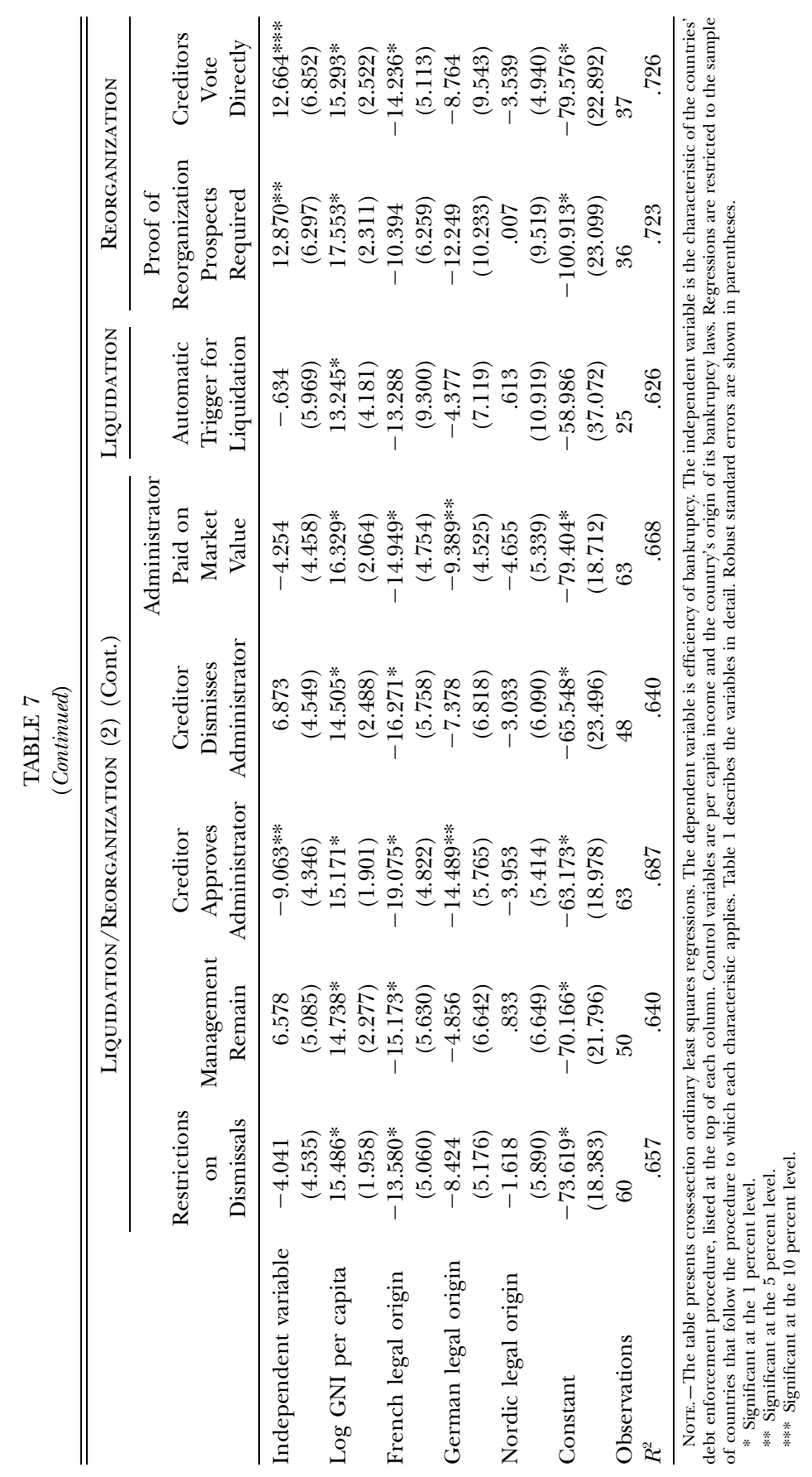


TABLE 8

Main Variable Averages by Procedure and Income Group, with and without Floating Charge

\begin{tabular}{|c|c|c|c|c|c|}
\hline \multirow[b]{2}{*}{ VARIABLE } & \multicolumn{2}{|c|}{ FORECLOSURE } & \multirow[b]{2}{*}{ LIQUIDATION } & \multirow[b]{2}{*}{ REORGANIZATION } & \multirow{2}{*}{$\begin{array}{c}\text { AVERAGE } \\
\text { BY } \\
\text { INCOME } \\
\text { GROUP }\end{array}$} \\
\hline & $\begin{array}{l}\text { Floating } \\
\text { Charge }\end{array}$ & $\begin{array}{l}\text { No Floating } \\
\text { Charge }\end{array}$ & & & \\
\hline & & & A. High Ince & & \\
\hline Time & .59 & 3.54 & 1.45 & 1.45 & 1.51 \\
\hline Cost $(\%)$ & 5.5 & 15.7 & 11.0 & 6.9 & 8.5 \\
\hline Going concern & 1.00 & .00 & .71 & .80 & .73 \\
\hline Efficiency & 91.02 & 43.32 & 73.21 & 81.52 & 77.35 \\
\hline \multirow[t]{2}{*}{ Observations } & 5 & 3 & 7 & 15 & 30 \\
\hline & \multicolumn{5}{|c|}{ B. Upper-Middle Income } \\
\hline Time & 2.31 & 2.98 & 2.83 & 2.69 & 2.80 \\
\hline Cost $(\%)$ & 9.0 & 15.2 & 17.3 & 14.8 & 15.7 \\
\hline Going concern & .00 & .00 & .30 & .33 & .20 \\
\hline Efficiency & 50.12 & 37.31 & 50.20 & 44.46 & 46.11 \\
\hline \multirow[t]{2}{*}{ Observations } & 2 & 5 & 10 & 3 & 20 \\
\hline & \multicolumn{5}{|c|}{ C. Lower-Middle Income } \\
\hline Time & 1.92 & 2.82 & 3.52 & 3.97 & 3.45 \\
\hline Cost $(\%)$ & 10.1 & 15.2 & 19.2 & 17.7 & 16.4 \\
\hline Going concern & .33 & .00 & .22 & .11 & .16 \\
\hline Efficiency & 51.46 & 39.30 & 32.20 & 31.70 & 35.03 \\
\hline \multirow[t]{2}{*}{ Observations } & 6 & 3 & 9 & 19 & 38 \\
\hline & \multicolumn{5}{|c|}{ D. Total } \\
\hline Time & 1.47 & 3.09 & 2.70 & 2.84 & 2.64 \\
\hline Cost $(\%)$ & 8.2 & 15.3 & 16.3 & 13.1 & 13.5 \\
\hline Going concern & .54 & .00 & .38 & .41 & .36 \\
\hline Efficiency & 66.47 & 39.49 & 50.16 & 52.93 & 51.97 \\
\hline Observations & 13 & 11 & 26 & 37 & 88 \\
\hline
\end{tabular}

Note.-The table presents the mean values of time, cost, expectation of keeping Mirage as a going concern, and efficiency of debt enforcement organized by both country income group and the debt enforcement procedure that applies in the case. Table 1 describes the variables in detail.

against Mirage are automatically stayed when bankruptcy proceedings commence. It is also uncorrelated with outcomes.

The next five variables cover the rules governing Mirage operations in bankruptcy proceedings. In some countries, Mirage ceases operations upon commencement of bankruptcy. Not surprisingly, this rule makes it less likely that Mirage survives as a going concern and is associated with lower efficiency (in the regression as well). In some countries, suppliers and customers may rescind contracts with Mirage without penalty upon the initiation of bankruptcy proceedings. This rule, more prevalent in the poorer countries, prolongs the case, prevents Mirage from continuing as a going concern, and is associated with sharply lower efficiency (in the regression as well). Some countries restrict dismissals by Mirage. Such restrictions reduce the likelihood that Mirage survives 
as a going concern and have an adverse, though not statistically significant, effect on efficiency. Finally, it does not appear to matter whether the management team of Mirage remains in control of ordinary business during bankruptcy proceedings. Again, this battery of variables yields a clear bottom line about what does not work in bankruptcy: measures that disrupt Mirage's operations during bankruptcy (which may have some logic to them, such as reduction of tunneling) for our case facts make it less likely that Mirage survives and therefore reduce efficiency.

The final group of all bankruptcy variables describes the control of the bankruptcy process and in particular the role of the creditors. The results in tables 5-7 do not provide consistent evidence that it matters whether Bizbank has the right to appoint or to dismiss the bankruptcy administrator or whether that administrator is paid on the basis of the market value of the estate.

We have one structural variable that pertains to liquidation only, namely, the presence of an "automatic trigger," such as a certain period of nonpayment, for liquidation. It is not correlated with efficiency.

Finally, we have two structural variables that deal with reorganization only. It appears beneficial for the cost, the likelihood of survival of Mirage, and overall efficiency that creditors vote directly rather than in a committee on the reorganization plan. This means that giving less voting power to unsecured creditors is better for efficiency, in line with the theoretical prediction for Mirage. And it does not seem to matter whether the law requires a proof of reorganization prospects before reorganization is attempted.

We have already mentioned the regression results in table 7 , where we control for both per capita income and legal origin, so here is just a brief summary. In virtually all regressions, French legal origin continues to exert an adverse influence on efficiency and per capita income a positive influence. Our structural characteristics do not kill these enormously powerful effects. For foreclosure, out-of-court seizure and sale of assets, as well as floating charge debt contracts, are conducive to higher efficiency. For bankruptcy, it is beneficial from the standpoint of efficiency for the bankruptcy proceedings to continue during appeal and for the same judge who made an initial ruling to hear the appeal as well. We also see that cessation of operations upon entering bankruptcy and allowing suppliers and customers to rescind contracts are both associated with lower efficiency. Finally, the results confirm that it is beneficial for creditors to vote directly rather than in a committee, which means that more power to Bizbank is good.

In summary, there are four robust bottom lines for our case facts. First, foreclosure works best with maximum creditor rights, minimum court involvement, and floating charge debt contracts. Second, a robust strategy for reducing the time and improving the efficiency of bank- 
TABLE 9

Private Credit/GDP Regressions

Dependent Variable: Private Credit/GDP (Average 1999-2003)

\begin{tabular}{|c|c|c|c|c|c|c|}
\hline Independent Variable & (1) & (2) & (3) & (4) & $(5)$ & (6) \\
\hline GDP & $\begin{array}{c}.093^{*} \\
(.018)\end{array}$ & $\begin{array}{c}.083^{*} \\
(.021)\end{array}$ & $\begin{array}{l}.088^{*} \\
(.019)\end{array}$ & $\begin{array}{l}.104^{*} \\
(.019)\end{array}$ & $\begin{array}{l}.097^{*} \\
(.021)\end{array}$ & $\begin{array}{l}.100 * \\
(.020)\end{array}$ \\
\hline GDP per capita growth & $\begin{array}{c}.011 \\
(.013)\end{array}$ & $\begin{array}{c}.009 \\
(.010)\end{array}$ & $\begin{array}{c}.009 \\
(.010)\end{array}$ & $\begin{array}{c}.018 \\
(.015)\end{array}$ & $\begin{array}{c}.017 \\
(.012)\end{array}$ & $\begin{array}{c}.015 \\
(.012)\end{array}$ \\
\hline Inflation & $\begin{array}{c}-.001 \\
(.001)\end{array}$ & $\begin{array}{c}-.001 \\
(.001)\end{array}$ & $\begin{array}{c}-.001 \\
(.001)\end{array}$ & $\begin{array}{c}-.001 \\
(.001)\end{array}$ & $\begin{array}{c}-.001 \\
(.001)\end{array}$ & $\begin{array}{c}-.002 * * \\
(.001)\end{array}$ \\
\hline Contract enforcement days & $\begin{array}{c}-.081 * * * \\
(.043)\end{array}$ & $\begin{array}{c}-.070 * * * \\
(.043)\end{array}$ & $\begin{array}{c}-.078^{* *} * \\
(.036)\end{array}$ & $\begin{array}{c}-.118^{*} \\
(.045)\end{array}$ & $\begin{array}{c}-.106^{* * *} \\
(.044)\end{array}$ & $\begin{array}{c}-.111^{*} \\
(.036)\end{array}$ \\
\hline Creditor rights index & & & $\begin{array}{l}.100^{*} \\
(.030)\end{array}$ & & & $\begin{array}{l}.108^{*} \\
(.029)\end{array}$ \\
\hline Information sharing & & & $\begin{array}{l}.200^{*} \\
(.066)\end{array}$ & & & $\begin{array}{l}.193^{*} \\
(.067)\end{array}$ \\
\hline Efficiency & $\begin{array}{l}.006^{*} \\
(.002)\end{array}$ & $\begin{array}{l}.006^{*} \\
(.002)\end{array}$ & $\begin{array}{l}.005^{*} \\
(.002)\end{array}$ & & & \\
\hline Efficiency with constant $8 \%$ & & & & $\begin{array}{l}.004^{* * * *} \\
(.002)\end{array}$ & $\begin{array}{c}.003 \\
(.003)\end{array}$ & $\begin{array}{l}.003^{* * *} \\
(.002)\end{array}$ \\
\hline French legal origin & & $\begin{array}{c}-.109 \\
(.107)\end{array}$ & & & $\begin{array}{c}-.166 \\
(.105)\end{array}$ & \\
\hline German legal origin & & $\begin{array}{c}-.216^{* *} \\
(.099)\end{array}$ & & & $\begin{array}{c}-.231 * * \\
(.100)\end{array}$ & \\
\hline Nordic legal origin & & $\begin{array}{c}-.190 \\
(.152)\end{array}$ & & & $\begin{array}{c}-.158 \\
(.140)\end{array}$ & \\
\hline Constant & $\begin{array}{r}-1.577^{*} \\
(.515)\end{array}$ & $\begin{array}{c}-1.276^{* *} \\
(.560)\end{array}$ & $\begin{array}{r}-1.790^{*} \\
(.477)\end{array}$ & $\begin{array}{r}-1.580^{*} \\
(.544)\end{array}$ & $\begin{array}{c}-1.271^{* *} \\
(.575)\end{array}$ & $\begin{array}{r}-1.835^{*} \\
(.489)\end{array}$ \\
\hline Observations & 84 & 84 & 84 & 84 & 84 & 84 \\
\hline$R^{2}$ & .556 & .584 & .646 & .519 & .550 & .617 \\
\hline
\end{tabular}

NOTE. - The table presents cross-section ordinary least squares regressions using a sample of 84 countries. The dependent variable is private credit as a share of GDP, averaged over 1999-2003. Independent variables are the country's GDP, GDP per capita growth, a measure of the efficiency of contract enforcement, the strength of creditor rights, the GDP, GDP per it in presence of credit information systems, the efficiency of the debt enforcennent procedure, the efficiency of the deb enforcement procedure assuming a constant 8 percent discount rate across all countries, and the origin of the country's bankruptcy laws. Table 1 describes the variables in detail. Robust standard errors are shown in parentheses.

* Significant at the 1 percent level.

* Significant at the 5 percent level.

*** Significant at the 10 percent level.

ruptcy proceedings is to circumscribe the appeals process. Third, bankruptcy rules that have the effect of stopping or curtailing the operations of Mirage during bankruptcy are not conducive to efficiency. Fourth, voting procedures that reduce the power of unsecured creditors work well in our case.

\section{Debt Market Development}

Do our measures of efficiency of debt enforcement predict the development of debt markets? Following the work of La Porta et al. (1997, 1998) and Levine (1999), we present some basic regressions addressing this issue. These regressions cannot be given a causal interpretation but do provide some cross-validation of our efficiency measure.

Table 9 presents the now relatively standard specification (La Porta et al. 1997; Djankov, McLiesh, and Shleifer 2007) of the determinants 
of the ratio of private credit to GDP for the 84 countries with available data. We control for total GDP, GDP per capita growth, inflation, and contract enforcement days (a measure of the quality of the legal system). In some specifications, we include the creditor rights index and a measure of whether a county has a public or a private credit registry (information sharing). In other specifications, we control for legal origin.

The results confirm the earlier findings that the level of GDP and contract enforcement days are correlated with the ratio of private credit to GDP. Also as in earlier work, both the creditor rights index and information sharing predict the size of the private debt market (Haselman, Pistor, and Vig 2005; Djankov et al. 2007). Neither GDP per capita growth nor inflation is significant in any specification. There is no statistically significant residual adverse effect of French legal origin on private credit, although there remains one of German legal origin as compared to common law. Efficiency has a highly statistically significant positive effect on the private debt to GDP ratio. A 10-point increase in efficiency is associated with a 5-6-point higher ratio of debt to GDP (the mean is 57 percent and the standard deviation is 43 percent). These effects of efficiency fall by a third but remain significant at the 10 percent level in two out of three specifications when we compute efficiency using a fixed 8 percent discount rate for all countries. The reason for a weaker finding with fixed rates is that one source of inefficiency of debt enforcement is high interest rates, which are higher in countries with lower debt to GDP ratios. Overall, the findings in table 9 are consistent with the view that our efficiency of debt enforcement measure captures some empirically relevant aspects of creditor power.

\section{Conclusion}

We have found that debt enforcement around the world is highly inefficient, even in the relatively simple case we consider. The inefficiency comes from high administrative costs and long delays, but also from excessive piecemeal sales of viable businesses. The inefficiency is linked to underdevelopment, which probably proxies for poor public-sector capacity of a country, and to French legal origin, which probably proxies for excessive formalism of the debt enforcement process. The inefficiency is also related to such structural aspects of debt enforcement as ineffective collateral systems, poorly structured appeals, business interruptions during bankruptcy, and inefficient voting among creditors. The inefficiency correlates with underdeveloped debt markets, consistent with the view that failures of debt enforcement discourage lending.

The narrative that emerges from these findings is straightforward. Developing countries follow the rich ones and introduce elaborate bankruptcy procedures, presumably designed to save and rehabilitate insol- 
vent firms. In the rich countries, although these procedures are timeconsuming and expensive, they typically succeed in preserving the firm as a going concern. In the developing countries, in contrast, these procedures nearly always fail in their basic economic goal of saving the firm; in fact, 80 percent of insolvent businesses end up being sold piecemeal. The odds of saving the firm are especially low in the French legal origin countries, which have highly formal bankruptcy procedures.

Does our very simple case, which abstracts from some aspects of debt contracts, suggest any strategies for improving the available procedures? We note from the start that our findings do not apply to very large firms with complex capital structures. But such firms are very few in developing countries, and the resolution of their insolvency is heavily politicized anyhow. Presumably such firms end up in special bankruptcy regimes, no matter how inefficient. But what can we say about small and medium firms, which are the vast majority?

Under current arrangements, middle-income countries nearly always fail to save a viable firm, despite time and cost. This suggests that, for small and medium firms, poor countries should avoid debt enforcement mechanisms that involve detailed and extensive court oversight since the administrative capacity of their courts may not tolerate such proceedings. Simpler mechanisms, such as foreclosure with no or limited court oversight and floating charge, which essentially transfer control of the firm to the secured creditor, might be preferred. These simple mechanisms may work well in a broader set of circumstances than our case facts. For example, they should work well if the efficient outcome is to sell the firm piecemeal. The risk of tunneling by management also strengthens the case for quick foreclosure. Even when more than one creditor is secured, foreclosure should work well as long as there is one principal creditor with security over most assets. Such a creditor might even provide super-priority financing to save the firm.

More generally, in a developing country, less formalistic mechanisms might improve debt enforcement. For example, restricting appeals might shorten the proceedings and improve efficiency, as the case of Mexico illustrates (Gamboa-Cavazos and Schneider 2006). As countries become richer and the financial structures of more of their firms more complex, more elaborate proceedings, including reorganization, might become appropriate. But the data show that extensive public-sector involvement ahead of public-sector capacity fails in achieving its goals.

Debt enforcement reforms might conflict with other legal institutions of a country. For example, debt enforcement appears to be a victim of structural features of some civil law regimes, such as extensive appeals, reversal of priority in bankruptcy, and restrictions on "floating charge." The latter problem is particularly noteworthy since our evidence indicates that foreclosure with floating charge yields the highest levels of 
efficiency, consistent with theoretical predictions for our case facts. These prevailing rules might be embedded in the legal framework of a country, such as registration of assets or the rules on what may serve as collateral (Armour 2007). This said, restricting appeals in bankruptcy proceedings and moving toward absolute priority and to floating charge debt can be feasible under civil law as well. According to our evidence, many rather small changes in how debt enforcement is organized might have positive social payoffs.

\section{References}

Aghion, Philippe, Oliver Hart, and John Moore. 1992. "The Economics of Bankruptcy Reform.” J. Law, Econ., and Organization 8 (October): 523-46.

Armour, John. 2007. "The Law and Economics Debate about Secured Lending: Lessons for European Lawmaking.” Manuscript, Faculty of Law, Univ. Oxford.

Asquith, Paul, Robert Gertner, and David Scharfstein. 1994. "Anatomy of Financial Distress: An Examination of Junk-Bond Issuers.” Q.J.E. 109 (August): $625-58$.

Ayotte, Kenneth, and Hayong Yun. 2009. "Matching Bankruptcy Laws to Legal Environments." J. Law, Econ., and Organization, forthcoming.

Baird, Douglas. 1986. "The Uneasy Case for Corporate Reorganizations." J. Legal Studies 15 (January): 127-47.

Baird, Douglas, and Robert Rasmussen. 2002. "The End of Bankruptcy." Stanford Law Rev. 55 (December): 751-89.

Bebchuk, Lucian. 1988. "A New Approach to Corporate Reorganizations." Harvard Law Rev. 101 (January): 775-804.

Berglof, Erik, Gerard Roland, and Ernst-Ludwig von Thadden. 2007. "Optimal Debt Design and the Role of Bankruptcy.” Manuscript, http://ssrn.com/ abstract $=440501$.

Bolton, Patrick, and David Scharfstein. 1996. "Optimal Debt Structure and the Number of Creditors." J.P.E. 104 (February): 1-25.

Bris, Arturo, Ivo Welch, and Ning Zhu. 2006. "The Costs of Bankruptcy: Ch. 7 Liquidation versus Ch. 11 Reorganization.” J. Finance 61 (June): 1253-1303.

Chang, Tom, and Antoinette Schoar. 2007. "The Effect of Judicial Bias in Chapter 11 Reorganization.” Manuscript, Dept. Econ., Massachusetts Inst. Tech.

Claessens, Stijn, and Leora Klapper. 2005. "Bankruptcy around the World: Explanations of Its Relative Use." American Law and Econ. Rev. 7 (Spring): 25383.

Davydenko, Sergei, and Julian Franks. 2008. "Do Bankruptcy Codes Matter? A Study of Defaults in France, Germany and the U.K.” J. Finance 63 (April): 565-608.

Djankov, Simeon, Edward Glaeser, Rafael La Porta, Florencio Lopez-de-Silanes, and Andrei Shleifer. 2003. "The New Comparative Economics." J. Comparative Econ. 31 (December): 595-619.

Djankov, Simeon, Oliver Hart, Caralee McLiesh, and Andrei Shleifer. 2006. "Debt Enforcement around the World," Working Paper no. 12807 (December), NBER, Cambridge, MA.

Djankov, Simeon, Rafael La Porta, Florencio Lopez-de-Silanes, and Andrei Shleifer. 2003. "Courts." Q.J.E. 118 (May): 453-517. 
Djankov, Simeon, Caralee McLiesh, and Andrei Shleifer. 2007. "Private Credit in 129 Countries." J. Financial Econ. 84 (May): 299-329.

Franks, Julian, and Gyöngyi Lóránth. 2005. "A Study of Inefficient Going Concerns in Bankruptcy." Discussion Paper no. 5035 (May), Centre Econ. Policy Res., London, http://www.cepr.org/pubs/dps/DP5035.asp.

Franks, Julian, and Oren Sussman. 2005. "Financial Distress and Bank Restructuring of Small and Medium Size UK Companies." Rev. Finance 9 (March): 65-96.

Franks, Julian, and Walter Torous. 1989. "An Empirical Investigation of U.S. Firms in Reorganization.” J. Finance 44 (July): 747-69.

Gamboa-Cavazos, Mario, and Frank Schneider. 2006. "Bankruptcy as a Legal Process." Manuscript, Dept. Econ., Harvard Univ.

Gennaioli, Nicola, and Stefano Rossi. 2007. "Optimal Resolutions of Financial Distress by Contract." Manuscript, Stockholm School Econ.

Gertner, Robert, and David Scharfstein. 1991. "A Theory of Workouts and the Effects of Reorganization Law." J. Finance 46 (September): 1189-1222.

Gilson, Stuart, Kose John, and Larry Lang. 1990. "Troubled Debt Restructurings: An Empirical Study of Private Reorganization of Firms in Default.” J. Financial Econ. 27 (October): 315-53.

Haselmann, Rainer, Katharina Pistor, and Vikrant Vig. 2005. "How Law Affects Lending." Working Paper no. 285 (October), Law and Econ. Dept., Columbia Univ.

Johnson, Simon, Rafael LaPorta, Florencio Lopez-de-Silanes, and Andrei Shleifer. 2000. "Tunneling." A.E.R. Papers and Proc. 90 (May): 22-27.

Lambert-Moglianski, Ariane, Konstantin Sonin, and Ekaterina Zhuravskaya. 2007. "Are Russian Commercial Courts Biased? Evidence from a Bankruptcy Law Transplant." J. Comparative Econ. 35 (June): 254-77.

LaPorta, Rafael, Florencio Lopez-de-Silanes, Andrei Shleifer, and Robert Vishny. 1997. "Legal Determinants of External Finance.” J. Finance 52 (July): 113150.

1998. "Law and Finance." J.P.E. 106 (December): 1113-55.

LaPorta, Rafael, Florencio Lopez-de-Silanes, and Guillermo Zamarripa. 2003. "Related Lending." Q.J.E. 118 (February): 231-68.

Lerner, Josh, and Antoinette Schoar. 2005. "Does Legal Enforcement Affect Financial Transactions? The Contractual Channel in Private Equity." Q.J.E. 120 (February): 223-46.

Levine, Ross. 1999. "Law, Finance, and Economic Growth.” J. Financial Intermediation 8 (January): 36-67.

LoPucki, Lynn. 2003. "The Nature of the Bankrupt Firm: A Reply to Baird and Rasmussen's The End of Bankruptcy." Stanford Law Rev. 56 (December): 64571.

Qian, Jun, and Philip Strahan. 2007. "How Laws and Institutions Shape Financial Contracts: The Case of Bank Loans.” J. Finance 62 (December): 2803-34.

Stromberg, Per. 2000. "Conflicts of Interest and Market Illiquidity in Bankruptcy Auctions: Theory and Tests.” J. Finance 55 (December): 2641-92.

Thorburn, Karin. 2000. "Bankruptcy Auctions: Costs, Debt Recovery, and Firm Survival." J. Financial Econ. 58 (December): 337-68.

Weiss, Lawrence, and Karen Wruck. 1998. "Information Problems, Conflicts of Interest and Asset Stripping: Chapter 11's Failure in the Case of Eastern Airlines." J. Financial Econ. 48 (April): 55-97.

White, Michelle. 1989. "The Corporate Bankruptcy Decision." J. Econ. Perspectives 3 (Spring): 129-51. 